Aquatic Macroinvertebrates and Water Quality of Sandia Canyon, Los Alamos National Laboratory, November 1993 to October 1994 
Primary field personnel:

Thomas Gonzales, UGS (ESH-20) and

Leonard Sandoval, UGS (ESH-20).

An Affirmative Action/Equal Opportunity Employer

This report was prepared as an account of work sponsored by an agency of the United States Government. Neither The Regents of the University of Califormia, the United States Government nor any agency thereof, nor any of their employees, makes any warranty, express or implied, or assumes any legal liability or responsibility for the accuracy, completeness, or usefulness of any information, apparat us, product, or process disclosed, or represents that its use would not infringe privately owned rights. Reference herein to any specific commercial product, process, or service by trade name, trademark, manufacturer, or otherwise, does not necessarily constitute or imply its endorsement, recommendation, or favoring by The Regents of the University of California, the United States Government, or any agency thereof. The views and opinions of authors expressed herein do not necessarily state or reflect those of The Regents of the University of Californin, the United States Government, or any agency thereof. 


\section{DISCLAIMER}

Portions of this document may be illegible in electronic image products. Images are produced from the best available original document. 
Aquatic Macroinvertebrates and Water Quality of Sandia Canyon, Los Alamos National Laboratory, November 1993 to October 1994 Saul Cross 



\section{TABLE OF CONTENTS}

LIST OF FIGURES $\quad$ v

1. Location of Los Alamos National Laboratory, New Mexico. 5

2. National Wetland Inventory map for Sandia Canyon, Los Alamos County, New Mexico (developed by U. S. Fish and Wildlife Service). $\quad 8$

3. Locations of sampling stations within Sandia Canyon. 9

4. Monthly water temperatures in Sandia Canyon, November 1993 through October 1994.

5. Monthly pH in Sandia Canyon, November 1993 through October 1994.

6. Departure from natural $\mathrm{pH}$ versus an Environmental Quality Index (Battelle 1972).

7. Monthly dissolved oxygen in Sandia Canyon, November 1993 through October 1994.

8. Monthly percent of dissolved oxygen saturation in Sandia Canyon, November 1993 through October 1993.

9. Percent of dissolved oxygen saturation versus an Environmental Quality Index (Battelle 1972).

10. Monthly conductivity in Sandia Canyon, November 1993 through October 1994.

11. Monthly total dissolved solids in Sandia Canyon, November 1993 through October 1994.

12. Total dissolved solids versus an Environmental Quality Index (Battelle 1972).

13. Number of taxa collected in Sandia Canyon, November 1993 through October 1994.

14. Number of individual macroinvertebrates collected in Sandia Canyon, November 1993 through October 1994. 
15. Wilhm's biodiversity values for Sandia Canyon sampling stations, November 1993 through October 1994.

LIST OF TABLES

vi

1. Water Quality Parameter Yearly Averages for Sandia Canyon Sampling Stations, November 1993 through October 1994.

2. Monthly Average, Total, and Two-Most-Populous Month Numbers of Macroinvertebrates for Sandia Canyon Sampling Stations, November 1993 through October 1994.

3. Yearly Community Tolerance Quotients for Sandia Canyon Sampling Stations, November 1993 through October 1994.

4. Chief Functional Feeding Groups of Aquatic Insects.

5. Yearly Averages of Wilhm's Biodiversity Values for Sandia Canyon Sampling Stations, November 1993 through October 1994.

ABSTRACT

1 INTRODUCTION 1

2 ENVIRONMENTAL SETTING

2.1 General Setting 4

2.2 Description of Sandia Canyon 6

2.3 Description of Study Sites 7

3 HISTORICAL DISTURBANCES IN SANDIA CANYON 10

3.1 Rubble Landfill 11

3.2 County Landfill 11

3.3 Accidental Spills 11

3.4 Overall Habitat Degradation $\quad 12$

4 METHODOLOGY 12

4.1 Water Quality Measurements 12

4.2 Aquatic Macroinvertebrate Sampling 13

4.3 Macroinvertebrate Analysis 13

5 RESULTS AND DISCUSSION 15

5.1 Water Quality Measurements 15

5.1.1 Temperature 15

$\begin{array}{ll}5.1 .2 \mathrm{pH} & 17\end{array}$ 
5.1.3 Dissolved Oxygen (DO) 17

5.1.4 Conductivity and Total Dissolved Solids (TDS) 21

5.2 Aquatic Macroinvertebrate Analysis 27

5.2.1 Total Numbers and Taxa $\quad 27$

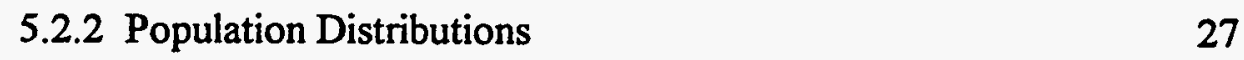

5.2.3 Tolerance Quotients 30

5.2.4 Community Structure $\quad 31$

$\begin{array}{ll}5.2 .5 \text { Biodiversity } & 32\end{array}$

6 CONCLUSIONS 32

$\begin{array}{ll}\text { ACKNOWLEDGMENTS } & 35\end{array}$

$\begin{array}{ll}\text { REFERENCES } & 36\end{array}$

APPENDICES vii

Appendix A: Macroinvertebrate Taxa Collected in Upper Sandia Canyon, November 1993 through October 1994

Appendix B: Aquatic Invertebrates Collected in Los Alamos County and Adjacent Watersheds

Appendix C: Tolerance Quotients of Aquatic Insects Collected in Sandia Canyon, November 1993 through October 1994

Appendix D: Mode of Existence of Aquatic Insects Collected in Sandia Canyon, November 1993 through October 1994

Appendix E: Functional Feeding Groups of Aquatic Insects Collected in Sandia Canyon, November 1993 through October 1994 


\title{
AQUATIC MACROINVERTEBRATES AND WATER QUALITY OF SANDIA CANYON, LOS ALAMOS NATIONAL LABORATORY NOVEMBER 1993-OCTOBER 1994
}

\author{
by
}

\author{
Saul Cross
}

\begin{abstract}
The Ecological Studies Team (EST) of ESH-20 at Los Alamos National Laboratory (LANL) has collected samples from the stream within Sandia Canyon since the summer of 1990 . These field studies gather water quality measurements and collect aquatic macroinvertebrates from permanent sampling sites. Reports by Bennett (1994) and Cross (1994) discuss previous EST aquatic studies in Sandia Canyon. This report updates and expands those findings.

EST collected water quality data and aquatic macroinvertebrates at five permanent stations within the canyon from November 1993 through October 1994. The two upstream stations are located below outfalls that discharge industrial and sanitary waste effluent into the stream, thereby maintaining yearround flow.

Some water quality parameters are different at the first three stations from those expected of natural streams in the area, indicating degraded water quality due to effluent discharges. The aquatic habitat at the upper stations has also been degraded by sedimentation and channelization. The macroinvertebrate communities at these stations are characterized by low diversities and unstable communities. In contrast, the two downstream stations appear to be in a zone of recovery, where water quality parameters more closely resemble those found in natural streams of the area. The two lower stations have increased macroinvertebrate diversity and stable communities, further indications of downstream water quality improvement.
\end{abstract}

\section{INTRODUCTION}

In the summer of 1990 , an accidental spill from the TA-3 power plant environment tank released more than 3,785 liters (1,000 gallons) of sulfuric acid into upper Sandia Canyon. The Ecolgocial Studies Team (EST) was asked to review the impacts of the spill and began regular monitoring of the Sandia wetlands at this time (Bennett 1994). The EST 
initiated a study to assemble baseline information on the aquatic environment in Sandia Canyon and to determine if the environment was affected by industrial and sanitary waste discharges. In addition to monitoring chemical and physical conditions (temperature, dissolved oxygen, $\mathrm{pH}$, and conductivity) of the stream monthly, the EST collected aquatic invertebrates to gain a more complete understanding of Sandia Canyon's aquatic environment.

In a report for the Bureau of Reclamation (Battelle 1972), Battelle Columbus Laboratories outlined a comprehensive and interdisciplinary Environmental Evaluation System (EES). This EES uses physical, chemical, and biological parameters to assess possible environmental impacts of water resource projects. This report refers to many of the environmental quality ratings developed by Battelle.

Water temperature directly influences aquatic organisms' physiological functions such as metabolism, growth, emergence, and reproduction (Anderson and Wallace 1984). Temperature is inversely related to oxygen solubility because water absorbs greater amounts of oxygen at lower temperatures. While aquatic organisms can tolerate wide fluctuations in $\mathrm{pH}$ and conductivity, a change in water temperature of a single degree Celsius can be significant (Lehmkuhl 1979).

Depressed oxygen environments often indicate the presence of organic wastes. The amount of dissolved oxygen (DO) in water has a direct and immediate effect on invertebrates using tracheal gills for respiration (as the larvae of dragonflies, mayflies, caddisflies, and stoneflies). Oxygen is present in air at levels greater than $200,000 \mathrm{ppm}$, but its maximum value at saturation in water is only $15 \mathrm{ppm}$ (Eriksen et al. 1984). Although aquatic insects require more oxygen for metabolism at elevated temperatures, less is available due to decreased solubility (Gaufin et al. 1974). Certain stages in the life cycle of aquatic invertebrates, such as emergence, will not occur unless sufficient oxygen is present (Bell 1971). Cold-water mayflies and stoneflies cannot tolerate DO concentrations much below $5 \mathrm{mg} / \mathrm{l}$ (Nebeker 1972). 
Acid waters are characterized by low species diversity and low productivity. Acidity and basicity of waters is measured by the $\mathrm{pH}$ scale with low values indicating acidity, middle values (around 7.0) indicating neutrality, and high values indicating basicity. Some aquatic organisms, as mayflies, are sensitive to low $\mathrm{pH}$, which can be caused by accidental acid spills or acid rain deposition. The normal $\mathrm{pH}$ of natural surface waters ranges from 6.5 to 9.0 (Canter and Hill 1979). In nearby Los Alamos Canyon, the $\mathrm{pH}$ of natural surface waters ranges between 7.8 and 8.2 (LANL 1990).

Conductivity measures the ability of water to carry an electrical current, and it reflects the concentrations of ionized substance in water. The conductivity of potable water in the United States ranges from 50 to 1,500 micro-mhos per centimeter ( $\mu \mathrm{mhos} / \mathrm{cm}$ ), and the conductivity of industrial waste may be as high as $10,000 \mu \mathrm{mhos} / \mathrm{cm}$. A rough approximation of the total dissolved solids (TDS) of freshwater in $\mathrm{mg} / \mathrm{l}$ can be obtained by multiplying the conductivity by 0.66 . The upper limit of TDS that aquatic organisms can tolerate ranges from 5,000 to $10,000 \mathrm{mg} / 1$ (Battelle 1972).

Aquatic macroinvertebrates have been extensively used as water quality indicators. A macroinvertebrate is an invertebrate that is visible to the unaided eye. This report uses the terms macroinvertebrate, aquatic macroinvertebrate, invertebrate, and aquatic invertebrate interchangeably. These organisms, especially the stream-dwelling insects, are well suited to this purpose due to their

- small size and total immersion in the water environment,

- relatively sedentary nature,

- abundance in virtually every stream,

- range of sensitivities to stress and contaminants,

- life cycles which are frequently of at least one year duration, allowing long-term detection of past disturbance, and

- relative ease of collection and identification to family or genus level.

In general, monitoring only the physical and chemical characteristics of waters provides little information of conditions prior to the sampling date. In contrast, changes in macroinvertebrate communities indicate water quality over a much longer period 
(Rosenberg et al. 1986). Failure of chemical criteria to protect aquatic life has necessitated incorporation of biological criteria into water resource management planning (Karr 1991). Shits in the numbers of individuals and community species composition indicate prior disturbances. These disturbances could result from infrequent discharges of waste that might remain undetected through a water quality monitoring program that did not incorporate biological data (Weber 1973).

Biological assessments reduce the complexity of an ecosystem, allowing management to make informed decisions and take appropriate actions (Intergovernmental Task Force on Monitoring Water Quality 1994). According to the Intergovernmental Task Force on Monitoring Water Quality (1992), objectives of an aquatic biological monitoring program should include

- defining status and trends

- identifying existing and emerging problems

- providing information to support development and implementation of policies and programs for water-resource management

- evaluating program effectiveness

- responding to emergencies.

\section{ENVIRONMENTAL SETTING}

\subsection{General Setting}

Sandia Canyon is located within the boundaries of Los Alamos National Laboratory (LANL). The Laboratory is located in north-central New Mexico on the Pajarito Plateau, approximately 120 kilometers ( 80 miles) north of Albuquerque and 40 $\mathrm{km}(25 \mathrm{mi})$ west of Santa Fe (Fig. 1). The plateau is an apron of volcanic sedimentary rock stretching $33-40 \mathrm{~km}(20-25 \mathrm{mi})$ in a north-south direction and 8-16 km (5-10 mi) from east to west.

The average elevation of the plateau is 2,286 meters (7,500 feet). It slopes gently eastward from the edge of the Jemez Mountains, a volcanic rock complex situated along the northwest margin of the Rio Grande rift. From an elevation of approximately 1,890 


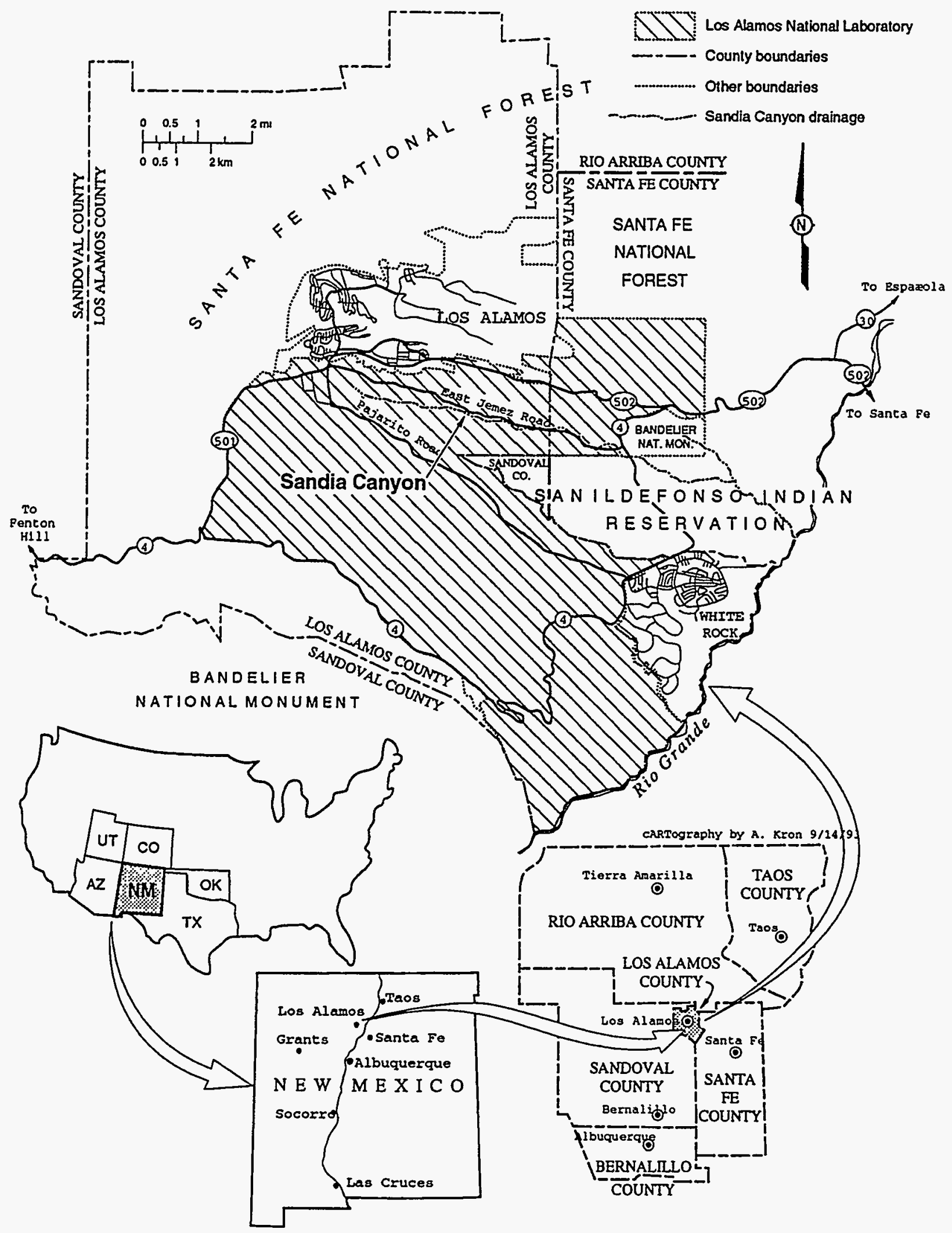

Fig. 1. Location of Los Alamos National Laboratory, New Mexico. 
meters $(6,200 \mathrm{ft})$ at White Rock, the scarp drops to 1,646 meters $(5,400 \mathrm{ft})$ at the Rio Grande. Intermittent streams flowing southeastward have dissected the plateau into a number of finger-like, narrow mesas separated by deep, narrow canyons. The bedrock of the plateau consists of Bandelier tuff erupted from the Jemez Mountains about 1.1 to 1.4 million years ago. The tuff overlaps other volcanics that, in turn, overlay the Puye Formation conglomerate (LANL 1988).

The LANL area is characterized by a semiarid, temperate, montane climate. In the summer months, temperatures typically range from a daily low of around $10^{\circ} \mathrm{C}\left(50^{\circ} \mathrm{F}\right)$ to a high of $27^{\circ} \mathrm{C}\left(80^{\circ} \mathrm{F}\right)$ (Bowen 1990). Winter temperatures generally range from near $-10^{\circ} \mathrm{C}$ $\left(15^{\circ} \mathrm{F}\right)$ to about $10^{\circ} \mathrm{C}\left(50^{\circ} \mathrm{F}\right)$ during a 24 -hour period. Annual precipitation varies from 33 to 46 centimeters (13 to 18 in.), most of it falling as rain in July and August.

\subsection{Description of Sandia Canyon}

The head of Sandia Canyon is near the University House in Technical Area 3 (TA3), and the canyon extends southeastward to the Rio Grande. The drainage basin is approximately 13.5 square kilometers (5.6 square miles). Industrial effluents from LANL activities maintain a year-round streamflow in Sandia Canyon.

The National Wetlands Inventory conducted by the U.S. Fish and Wildlife Service identified three types of wetlands or water systems in Sandia Canyon. EST's monitoring was conducted in the first stretch, a "persistent artificially flooded, palustrine wetland." This wetland occurs below TA-3 and receives effluent from the TA-3 steam plant, a sewage treatment plant, and an asphalt plant. This portion of the stream has received effluent discharges since the early 1950s. Several LANL outfalls discharge into a culvert at the head of the canyon, and a sanitary waste outfall discharges excess reuse water above SC2. Storm water runoff and snow melt also seasonally contribute to the stream.

Farther downstream, the stream crosses East Jemez Road. Here, the wetland area changes to a "temporarily flooded palustrine wetland" type. The stream's lower stretch is 
an "intermittent, temporarily flooded, riverine stream bed" (Cowardin 1979). The National Wetland Inventory map of Sandia Canyon is shown in Fig. 2.

\subsection{Description of the Study Sites}

In 1990, three permanent sample stations were placed in the artificially flooded, palustrine wetland in Sandia Canyon. In the winter of 1992, EST began to monitor two additional stations (Fig. 3) to better document the aquatic environment. The elevation of all five stations is approximately $2,360 \mathrm{~m}(7,200 \mathrm{ft})$ asl. All sampling stations are designated by the letters "SC" followed by a number, which indicates their relative positions along the stream, with higher number occuring upstream.

$\mathrm{SC} 1$ is at the base of the rubble landfill and immediately beyond the effluent culvert. It receives effluent from the steam plant and the asphalt plant. The streamside vegetation in this section consists of redtop (Agrostis alba) and cattails (Typha latifolia). Debris, including asphalt from the rubble landfill, is carried down a side channel and washed into the stream. The stream bed is mostly silts and sands, and there is little or no emergent vegetation within the stream channel. The water flow is highly variable at this station due to erratic releases from outfalls immediately above it. When effluent is discharged, the greatly increased flow suspends the easily erodable substrate and redeposits it downstream. Violent discharges sometimes result in the formation of a pool below the culvert. On the south, a nearby stand of young Douglas-fir (Pseudotsuga menziesii) and white fir (Abies concolor) appears to be dying.

$\mathrm{SC} 2$ is approximately $14 \mathrm{~m}(45 \mathrm{ft})$ beyond the culvert. The streamside vegetation consists of redtop, Canada wildrye (Elymus canadensis), thistle (Cirsium sp.), and cattails. This station is located immediately below the junction of the stream channel and a sewage treatment outfall. The outfall flow varied greatly during 1993, and it was frequently dry. The stream bed substrate consists of cobbles with abundant sands, silts, and gravel. At times, the smell of chlorine in the air is quite strong. 


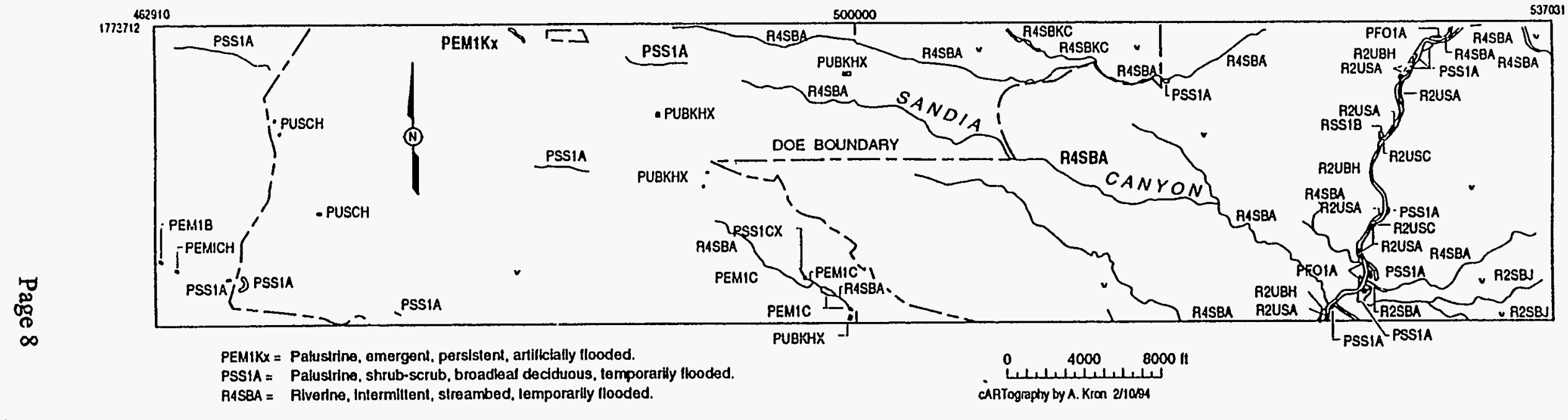

Fig. 2. National Wetland Inventory map for Sandia Canyon, Los Alamos County, New Mexico (developed by U.S. Fish and Wildlife Service). 


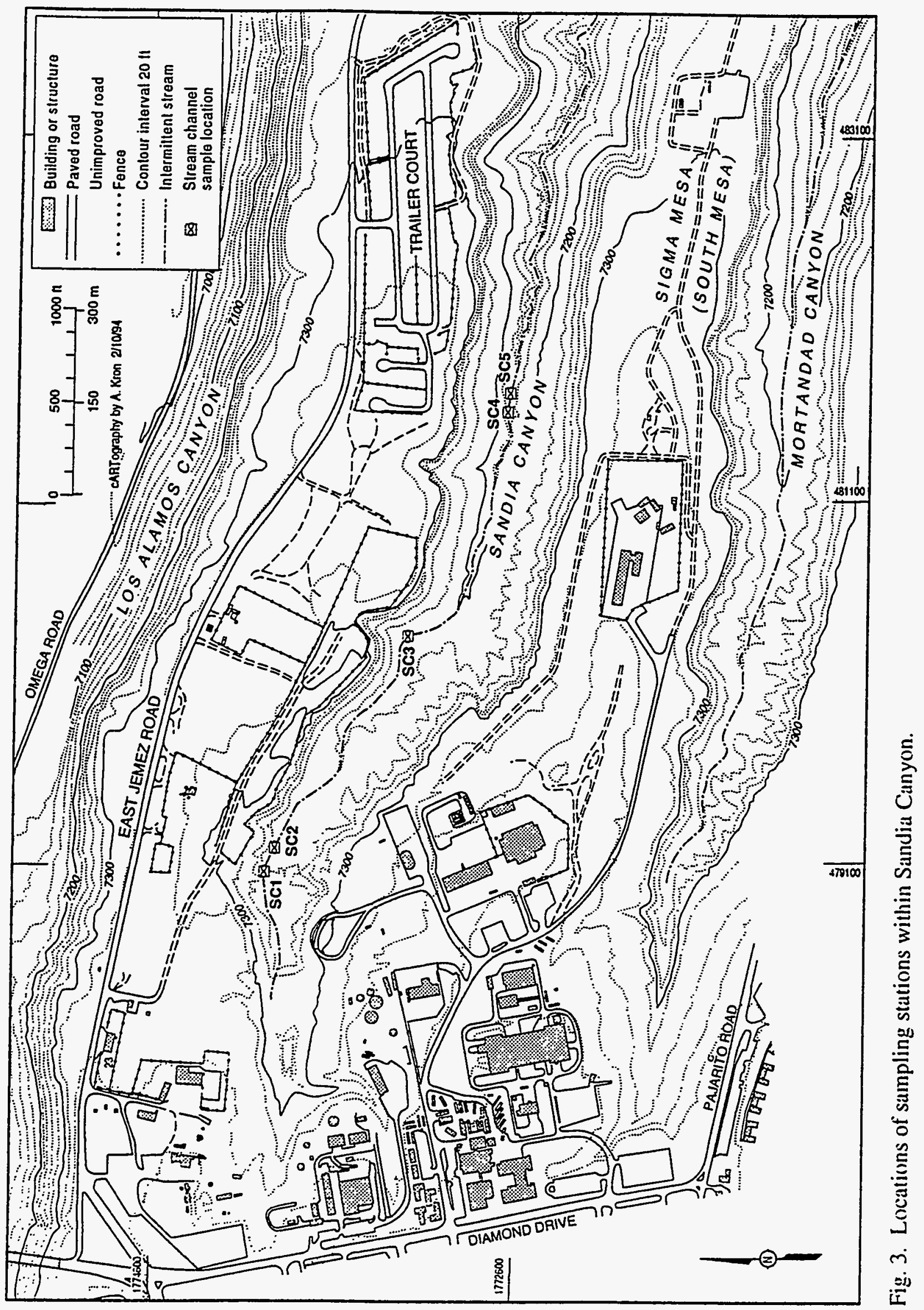

Page 9. 
SC3 is at a pool, approximately $0.4 \mathrm{~km}(0.25 \mathrm{mi})$ downstream from station $\mathrm{SC}$. The vegetation in this area is characterized by redtop and wheatgrass (Agropyron sp.) on the south side of the stream channel and cattails on the north side. The stream bed substrate consists of silts and sands containing a large quantity of humus. Water pools here, and the flow is much more stable than at $\mathrm{SC} 1$ and $\mathrm{SC} 2$.

SC4 is at a large pool below the cattail marsh, approximately $0.4 \mathrm{~km}(0.25 \mathrm{mi})$ downstream from station SC3. Nearby limber pine (Pinus flexilis) and ponderosa pine (Pimus ponderosa) provide some shade. The vegetation is limited by exposed bedrock which surrounds the pool. Nearby vegetation includes June grass (Koleria cristata), Canada wildrye, and little bluestem (Andropogon scoparius). The stream substrate consists of sand and silt deposited on top of rock. In November of 1993, EST began to sample the north side of the pool (the south side had been used in previous years). The north side did not contain the submerged vertical rock faces found on the south side and favored by larvae of Odonates (dragonflies and damselflies) and Trichoptera (caddisflies).

In November of 1994, SC5 was moved approximately 50 meters (164 ft) downstream from its previous location. Streamside vegetation includes redtop, little bluestem, smooth brome (Bromus inermis), wild rose (Rosa woodsii), and mosses. Nearby ponderosa pine, willows (Salix sp.), and a few Douglas-firs (Pseudotsuga menziesii) provide some shade. The channel is approximately $0.6 \mathrm{~m}(2 \mathrm{ft}$.) deep, and bedrock is exposed along much of the watercourse. The current is swift enough to remove most sand and silts from the main channel, and these fine sediments are deposited on the sides and in the slower reaches. The stream bed contains few cobbles, limiting the suitability of aquatic macroinvertebrate habitat.

\section{HISTORICAL DISTURBANCES IN SANDIA CANYON}

In addition to the impacts of routine effluent discharges, the hydrology of Sandia Canyon has been affected by the rubble landfill, Los Alamos County sanitary landfill, accidental chemical spills, and cumulative habitat degradation. 


\subsection{Rubble Landfill}

The rubble landfill was started in 1986 as an alternative disposal site for clean rubble. Presently, the landfill bridges the canyon and will be extended to the northeast. Large amounts of fill and sediments erode into the wetland during heavy storms and snow melt. Recent attempts have been made to stabilize the landfill and prevent eroding materials from entering the stream channel and wetland below. Dumping of asphalt over the side of the landfill aggravates the problem and pieces of asphalt continue to enter the stream channel.

\subsection{County Landfill}

The county landfill is located to the north of Sandia Canyon and extends $1.2 \mathrm{~km}$ ( $0.75 \mathrm{mi}$ ) along the top of Los Alamos Mesa. The landfill receives Los Alamos County business and residential refuse as well as sanitary refuse from LANL. Fill material erodes off the landfill and into the wetland. In addition, paper trash and other debris falls or blows into the canyon. At present, the stream between $\mathrm{SC} 2$ and $\mathrm{SC} 3$ is littered with metal poles, sheets of plastic, and other trash.

\subsection{Accidental Spills}

During the summer of $1990,3,785-5,300$ liters $(1,000-1,400$ gallons) of sulfuric acid spilled from the TA-3 power plant environmental tank into the cattail-dominated wetland in Sandia Canyon. Three of EST's five sampling stations were established at this time to assess the spill's impact. The stream channel was surveyed immediately after the spill for aquatic macroinvertebrates and no specimens were initially found at any of the sample locations. However, aquatic macroinvertebrate communities began to re-establish within one month. The sampling station now designated SC4 was the first site where recovery was observed.

During midsummer 1992, another spill discharged chlorine from the sewage treatment plant into Sandia Canyon. Subsequent investigation revealed a significant 
decline in the number of stream macroinvertebrates. By the end of summer, the numbers of macroinvertebrates had nearly returned to normal.

\subsection{Overall Habitat Degradation}

A properly functioning wetlands provides increased water retention, storm and flood abatement, groundwater recharge, sediment trapping, pollutant filtering, and wildlife habitat (Hill 1994). However, the wetlands in Sandia Canyon is not functioning properly, primarily due to anthropogenic stresses. These stressors include

- high chlorine levels in the upper canyon

- thermal pollution

- greatly fluctuating water levels, causing to channelization and scour

- high sedimentation loadsfrom the Los Alamos County landfill and the LANL, rubble dump

- asphalt and trash in the stream

- previous sewer line, which failed to restore the area to its natural contours

- loss of potential aquatic and wildlife habitat due to sedimentation, channelization, low plant diversity, and senescent cattails.

According to a recent Department of Energy compliance investigation of LANL wetlands (Kubik 1993), "The wetland at the head of Sandia Canyon has been, and continues to be, adversely impacted by chemical releases and other LANL activities assoicated with TA-3. Efforts should be made to prevent further disturbance of this wetland."

\section{METHODOLOGY}

\subsection{Water Quality Measurements}

EST attempted to measure the temperature, $\mathrm{pH}, \mathrm{DO}$, and conductivity of stream water monthly at all five sampling stations. Measurements were taken with calibrated instruments in accordance with the manufacturer's specifications. All measurements were taken three times; and the average value was used in computations.

Temperature measurements were taken with the temperature probe of an Orion SA-250 pH meter or a Yellow Springs Instrument model 57 DO meter. All pH measurements were taken with an Orion SA $250 \mathrm{pH}$ meter. DO was measured with a Yellow Springs Instrument model 57. DO readings were multiplied by a factor of 0.78 to 
compensate for the elevation in upper Sandia Canyon. All conductivity measurements were taken with a Van Waters Rogers digital conductivity meter which displays the conductivity in units of $\mu \mathrm{mhos} / \mathrm{cm}$. Estimates of total dissolved solids were obtained by multiplying the conductivity readings by 0.66 (Battelle 1972).

\subsection{Aquatic Macroinvertebrate Sampling}

Aquatic macroinvertebrates were collected monthly at the same time that water quality measurements were taken. The substrate at each station was agitated, and various microhabitats at each site were included. Sampling employed a large, D-frame dip net with a diameter of $11.5 \mathrm{~cm}$ ( $4.5 \mathrm{in}$.) at its widest point. The net was scraped against the stream bed for 60 seconds and then carefully removed from the water (Hilsenhoff 1977). All captured aquatic invertebrates were collected in scintillation vials containing $70 \%$ ethanol and taken to the EST lab for identification.

Organisms were identified using a Bausch and Lomb "Stereozoom 7" binocular dissecting microscope. Identification of specimens was accomplished using taxonomic references for southwestern macroinvertebrates including Pennack 1978, Merritt and Cummins 1984, Edmunds 1976, Baumann 1977, Wiggins 1978, and McCafferty 1981. Organisms were identified to genus when possible, and archived in the permanent EST invertebrate collection in $70 \%$ ethanol. Identifications were confirmed by $\mathrm{Dr}$. Gerald $\mathrm{Z}$. Jacobi of New Mexico Highlands University, a recognized expert on the aquatic macroinvertebrates of New Mexico.

\subsection{Aquatic Macroinvertebrate Analysis}

Many early water quality investigations attempted to measure species-specific invertebrate tolerances to pollution and compiled extensive species indicator lists. This method is prone to erroneous interpretations since species-level identification is difficult to ascertain, tolerances of some species vary greatly under different environmental conditions, and "intolerant" species may occur in polluted waters due to drift, i.e. transport by water currents. 
Recent studies have emphasized the importance of community structure in evaluating water quality (Gaufin and Tarzwell 1956; Hilsenhoff 1977; and Schwenneker and Hellenthal 1984). Diversity indices have been developed to allow numerical comparisons of whole macroinvertebrate communities. Unpolluted environments have higher taxa diversity index values than polluted environments, which tend to be dominated by relatively few tolerant species. EST reviewed the numbers of collected macroinvertebrates and population distributions by station. Invertebrate habits (modes of existence) and functional feeding groups were also examined to further elucidate community trends.

The Community Tolerance Quotient (CTQ) index was developed to assess the impacts of nonpoint source pollution in the western United States (Winget and Mangum 1979). This system has been previously used in the Jemez Mountains to effectively evaluate stream quality (Jacobi 1989, 1990, and 1992) and provides a more complete and accurate basis for site comparison than the PET (Plecoptera, Trichoptera, and Ephemeroptera) index. Tolerance quotients for aquatic macroinvertebrate taxa range from 6 (the most sensitive) to 108 (the least sensitive) and are based upon tolerances to alkalinity, sulfates, and sedimentation. The CTQ is computed using the formula

$$
\mathrm{CTQ}=\Sigma(\mathrm{xt}) / \mathrm{n}
$$

where

$$
\begin{aligned}
& x=\text { number of individuals within a species } \\
& t=\text { tolerance value of a taxon (found in a published table of values) } \\
& n=\text { total number of organisms in the sample }
\end{aligned}
$$

EST made a concerted effort to ensure that taxa were not counted twice; if a counting error occurred, it was due to under-counting rather than over-counting. Therefore, we only counted one taxon in a sample for the following cases:

- different life stages of a taxon present

- specimen(s) keyed to the family level and another specimen(s) in the same family identified to a lower level

- possible different instars of a genus assigned separate descriptive, rather than taxonomic, identifications. 
The data from each station were pooled, and a diversity index was calculated using the equation discussed by Wilhm (1967):

$$
\begin{array}{ll}
\text { where } & \mathrm{D}=\text { the taxa diversity index } \\
\mathrm{S}=\text { the number of taxa } \\
\mathrm{N}=\text { the number of individuals }
\end{array}
$$

The derived number reflects the site's taxa richness and evenness. A diversity index value of less than 1 indicates heavy pollution, between 1 and 3 indicates moderate pollution, and greater than 3 indicates clean water. However, biodiversity values for low-order montane streams are notoriously low and should not be compared to higher-order and lower elevation streams.

\section{RESULTS AND DISCUSSION}

\subsection{Water Quality Measurements}

5.1.1 Temperature. Fig. 4 shows the monthly temperatures recorded at each sample station in degrees Celsius. SC1 receives effluent from the TA-3 steam plant that is normally discharged at temperatures higher than the natural stream temperature; the 12month temperature averages were highest $\left(14.6^{\circ} \mathrm{C}\right.$ and $\left.15.0^{\circ} \mathrm{C}\right)$ at the upstream stations (Table 1). The lowest average water temperatures $\left(11.1^{\circ} \mathrm{C}\right)$ and were recorded at the stations farthest downstream from the site of effluent discharge. No recorded temperatures were in excess of the current State of New Mexico standards for a warmwater fishery (State of New Mexico 1995).

Table 1. Water Quality Parameter Yearly Averages for Sandia Canyon Sampling Stations, November 1993 through October 1994.

\begin{tabular}{|c|c|c|c|c|c|c|}
\hline $\begin{array}{c}\text { Sampling } \\
\text { Station }\end{array}$ & $\begin{array}{c}\text { Water } \\
\text { temperature } \\
\left({ }^{\circ} \mathbf{C}\right)\end{array}$ & $\mathbf{p H}$ & $\begin{array}{c}\text { Dissolved } \\
\text { oxygen } \\
(\mathbf{m g} / \mathbf{)})\end{array}$ & $\begin{array}{c}\text { Percent of } \\
\text { oxygen } \\
\text { saturation }\end{array}$ & $\begin{array}{c}\text { Conductivity } \\
\mu \mathrm{mhos} / \mathrm{cm}\end{array}$ & $\begin{array}{c}\text { TDS } \\
(\mathbf{m g} / \mathbf{)})\end{array}$ \\
\hline 1 & 14.6 & 8.5 & 7.82 & 75.9 & 816.2 & 538.8 \\
\hline 2 & 15.0 & 8.3 & 7.73 & 76.7 & 721.9 & 476.5 \\
\hline 3 & 13.0 & 7.8 & 7.33 & 66.9 & 704.3 & 464.8 \\
\hline 4 & 11.1 & 8.1 & 8.93 & 79.1 & 727.5 & 480.1 \\
\hline 5 & 11.1 & 8.2 & 8.99 & 80.8 & 701.6 & 463.3 \\
\hline
\end{tabular}




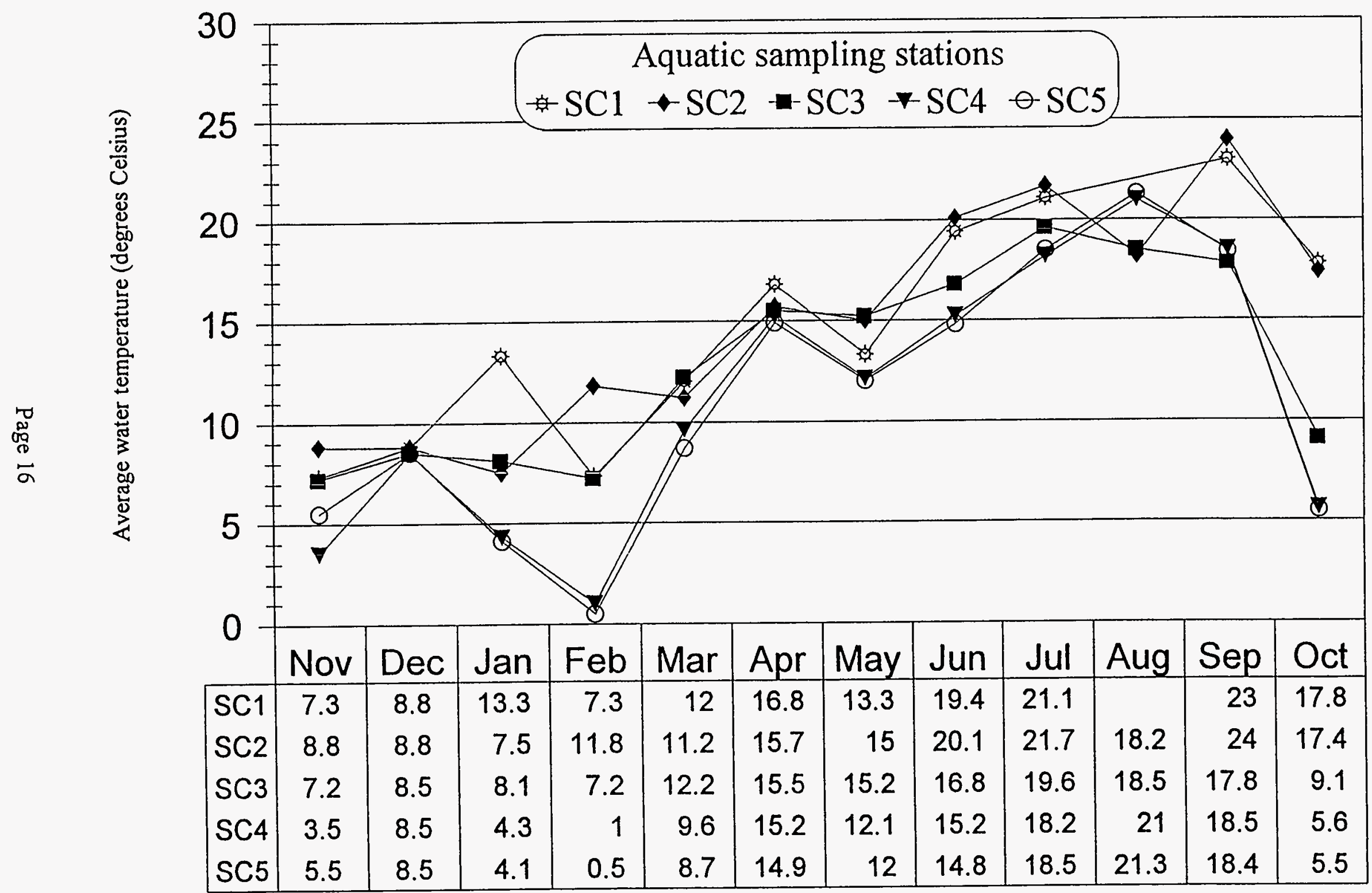

Figure 4. Monthly water temperatures in Sandia Canyon, November 1993 through October 1994. 
5.1.2 pH. Fig. 5 displays monthly $\mathrm{pH}$ readings from the five sample stations. The highest average $\mathrm{pH}$ readings usually occurred at $\mathrm{SCl}$ (Table 1). This is probably due to the influence of the steam plant effluent, which has a pH higher than the natural waters of the area. The maximum $\mathrm{pH}$ allowed for this outfall $(9.0)$ by the National Pollution Discharge Elimination System permit was exceeded in February 1994.

The lowest yearly average $\mathrm{pH}$ occurred at $\mathrm{SC} 3$, which had a 12-month average of 7.8. This value falls in low end of the range of natural waters in this area (7.8-8.2). In past sampling years, the low $\mathrm{pH}$ readings at $\mathrm{SC} 3$ were thought to be due to neutral $(\mathrm{pH}=7)$ effluent discharges from the sewage treatment plant. In an effort to determine the causative factor, EST included SC2 below the junction of this outfall in its 1993 monitoring program. In 1994, the yearly average $\mathrm{pH}$ at SC2 was 8.3, suggesting that another factor is responsible for the low $\mathrm{pH}$ downstream. SC3 is a low velocity pool within the cattail marsh where vegetation carried by the stream current is deposited. In all likelihood, the natural decomposition of this vegetation releases acidic products accounting for the low $\mathrm{pH}$ readings here.

The monthly $\mathrm{pH}$ readings ranged from 7.2 to 9.3. All of these values fall within the "excellent" or "good" ranges of the Environmental Water Quality Index based on $\mathrm{pH}$ (Battelle 1972; Fig. 6). A departure \pm 1 from the normal $\mathrm{pH}$ is considered insignificant to aquatic macroinvertebrates (Lehmkuhl 1979). In 47 of 50 readings, the $\mathrm{pH}$ measurements fell within the State of New Mexico standards for high quality coldwater fisheries (State of New Mexico 1995).

5.1.3 Dissolved Oxygen (DO). The highest yearly average DO readings occurred at SC4 $(8.93 \mathrm{mg} / \mathrm{l})$ and SC5 $(8.99 \mathrm{mg} /)$, while the lowest $(7.33 \mathrm{mg} / \mathrm{l})$ occurred at SC3 (Table 1). Fig. 7 displays the monthly DO concentrations in $\mathrm{mg} / \mathrm{l}$ from the five sample stations. In 54 of 55 measurements, the DO readings fell within the State of New Mexico standards for high quality coldwater fisheries (State of New Mexico 1995). 


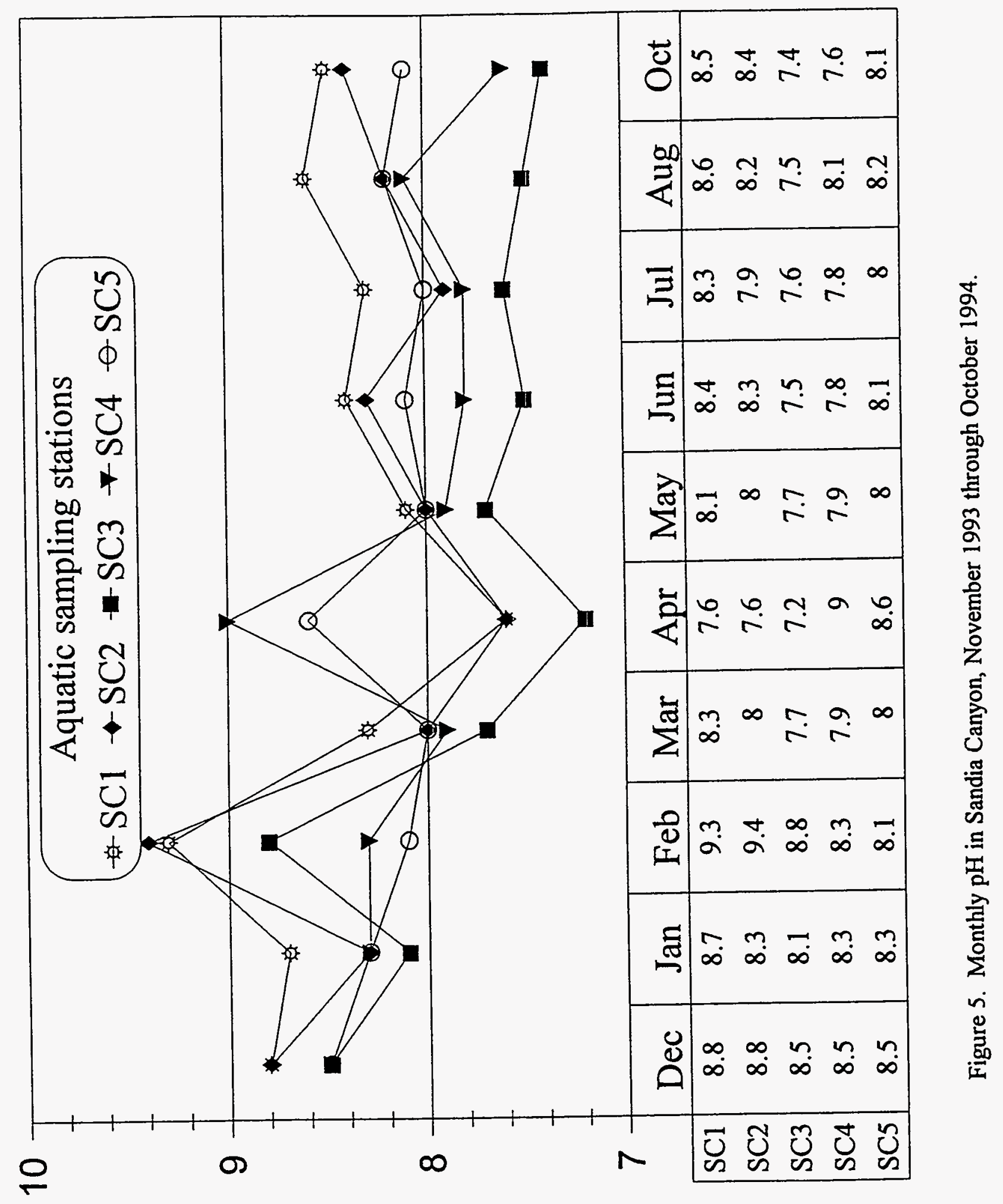




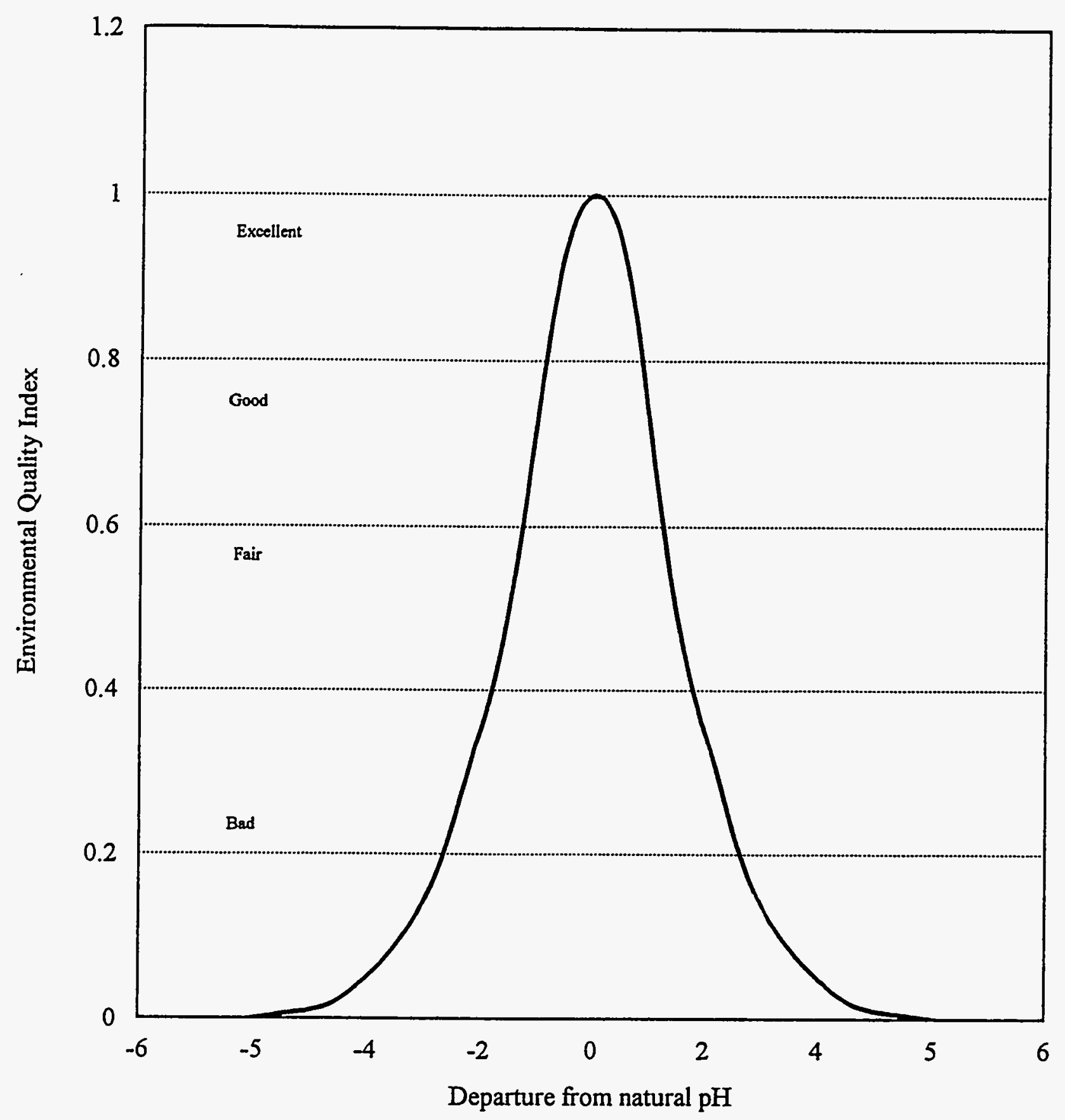

Fig. 6. Departure from natural pH versus an Environmental Quality Index (Battelle, 1972). 


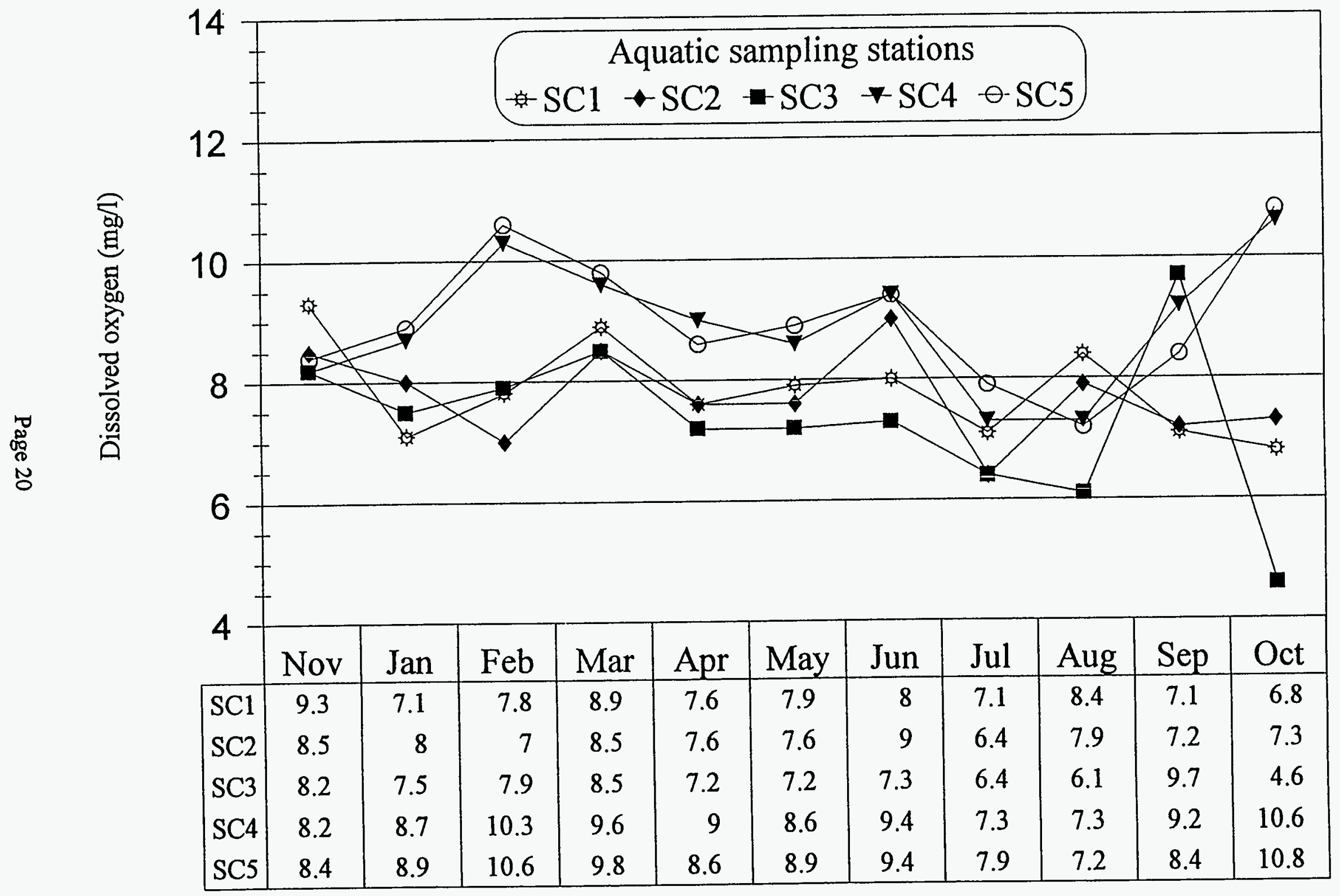

Figure 7. Monthly dissolved oxygen in Sandia Canyon, November 1993 through October 1994. 
Fig. 8 displays the monthly percent of DO saturation in water at the stations in Sandia Canyon. DO concentrations and percent saturation yearly averages (Table 1) were highest at SC4 (79.1) and SC5 (80.8) and lowest at SC3 (66.9). The low percent of DO saturation at SC3 is probably due to the natural decomposition of vegetation in the pool that also lowers the $\mathrm{pH}$.

A functional curve relating the percent of DO saturation to an Environmental Quality Index is shown in Fig. 9 (Battelle 1972). Based on the average percent of DO saturation, all sampling stations except SC3 are within the "excellent" range. SC3 falls within the "good" range.

5.1.4 Conductivity and Total Dissolved Solids (TDS). Monthly conductivity readings in $\mu \mathrm{mhos} / \mathrm{cm}$ are displayed in Fig. 10 and yearly averages are given in Table 1 . The highest monthly readings were recorded at $\mathrm{SC} 1$ in January $(1,912 \mu \mathrm{mhos} / \mathrm{cm})$ and $\mathrm{SC} 2$ in February $(2,008 \mu \mathrm{mhos} / \mathrm{cm})$. This elevation in conductivity can probably be attributed to an influx of ions from parking lot runoff, following the salting of roads to melt ice. In 52 of 55 measurements, the conductivity readings were below the maximum value set by the State of New Mexico for high-quality coldwater fisheries (State of New Mexico 1995).

A rough approximation of milligrams of TDS per liter of freshwater can be obtained by multiplying the conductivity by 0.66 . Fig. 11 illustrates estimated monthly TDS concentrations from the five stations and Table 1 lists the yearly averages. The TDS concentrations occur within the "excellent" range of the Environmental Quality Index developed by Battelle (Fig. 12) in all but three cases which fall within the "good" range. The highest TDS concentration recorded was $1325 \mathrm{mg} / \mathrm{l}$ at SC2 in February. Aquatic organisms can generally tolerate TDS concentrations as high as $5000 \mathrm{mg} / \mathrm{l}$, a concentration much higher than any found at the sampling stations. 


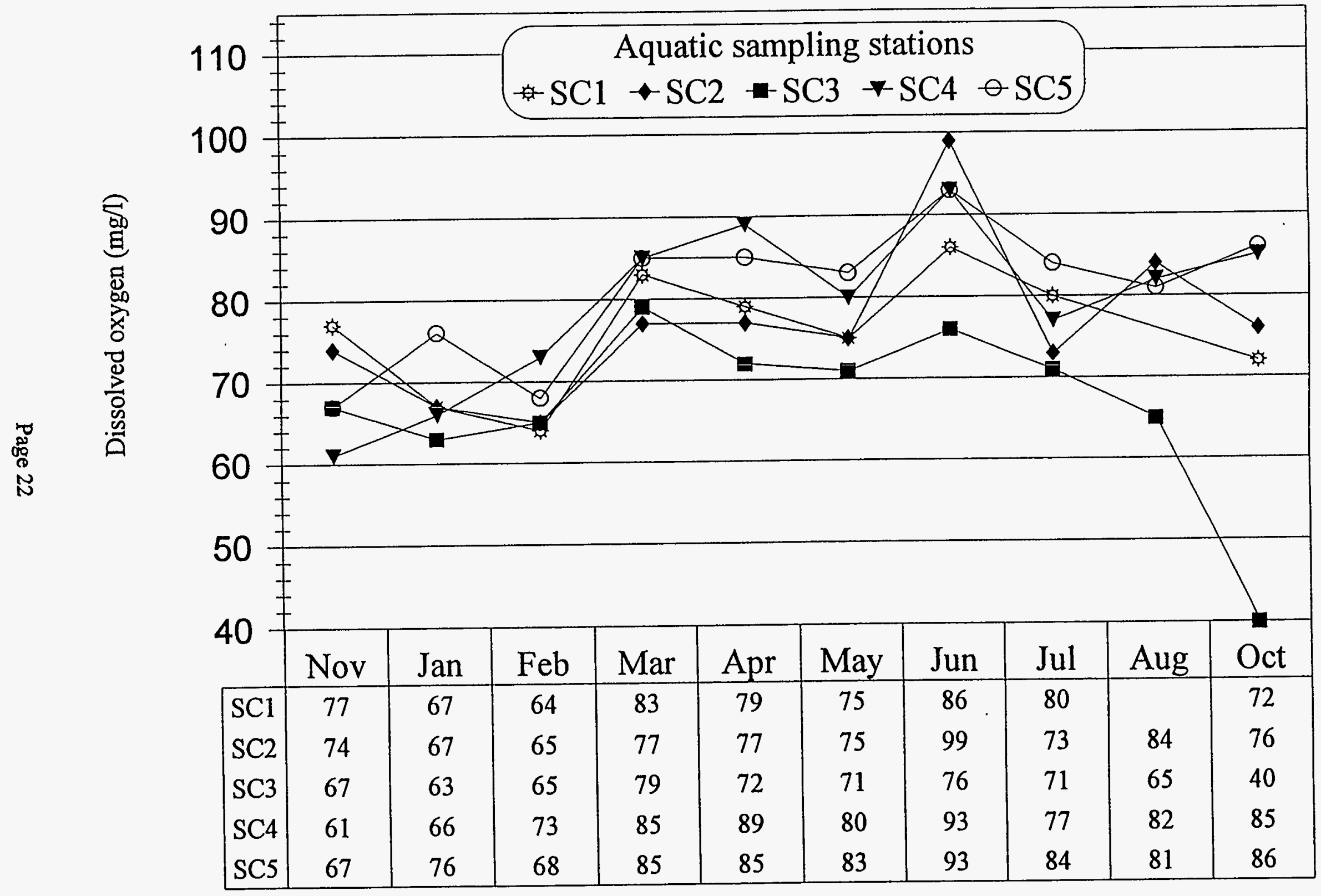

Figure 8. Monthly percent of dissolved oxygen saturation in Sandia Canyon, November 1993 through October 1994. 


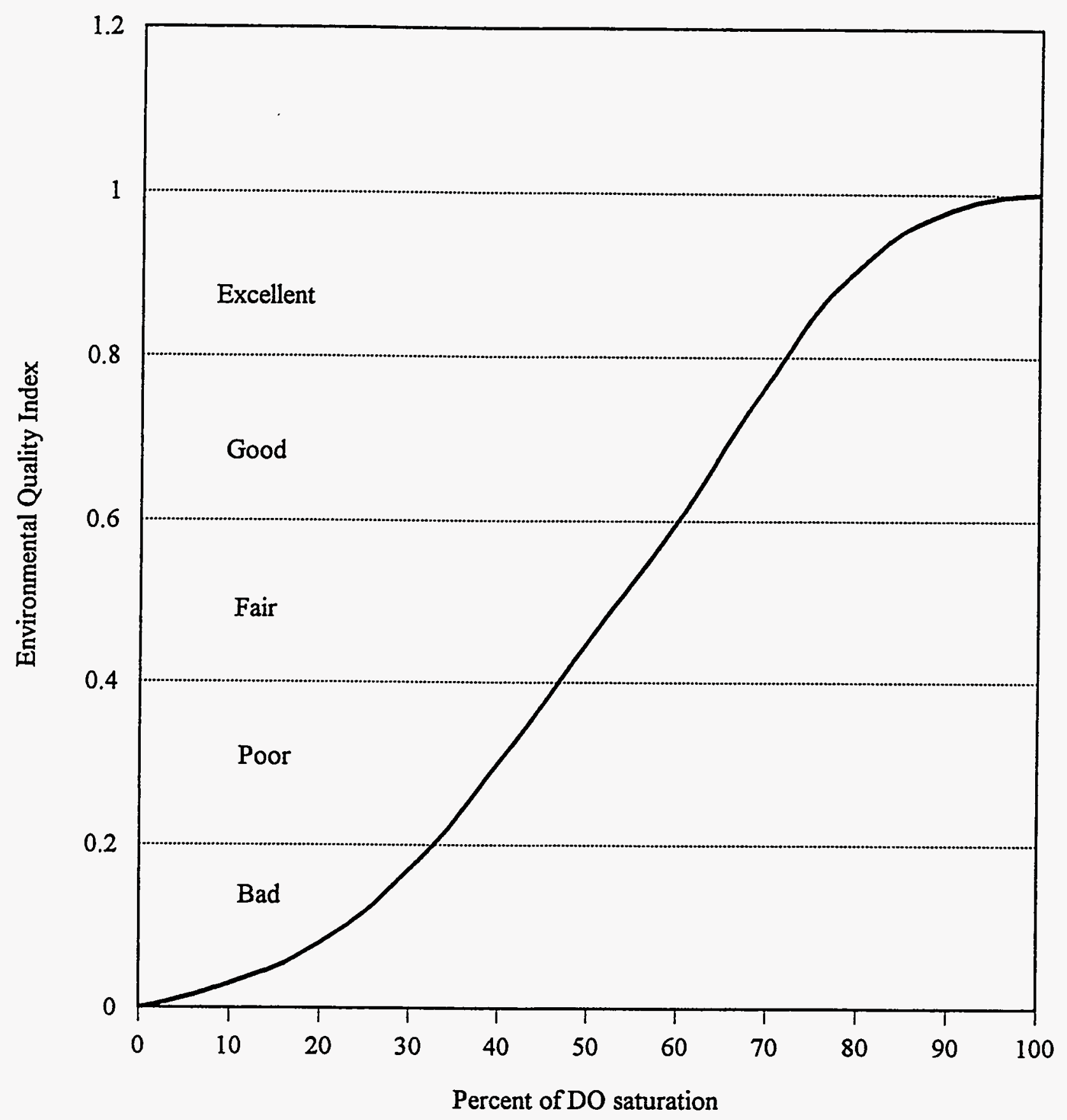

Fig. 9. Percent of DO saturation versus an Environmental Quality Index (Battelle, 1972). 


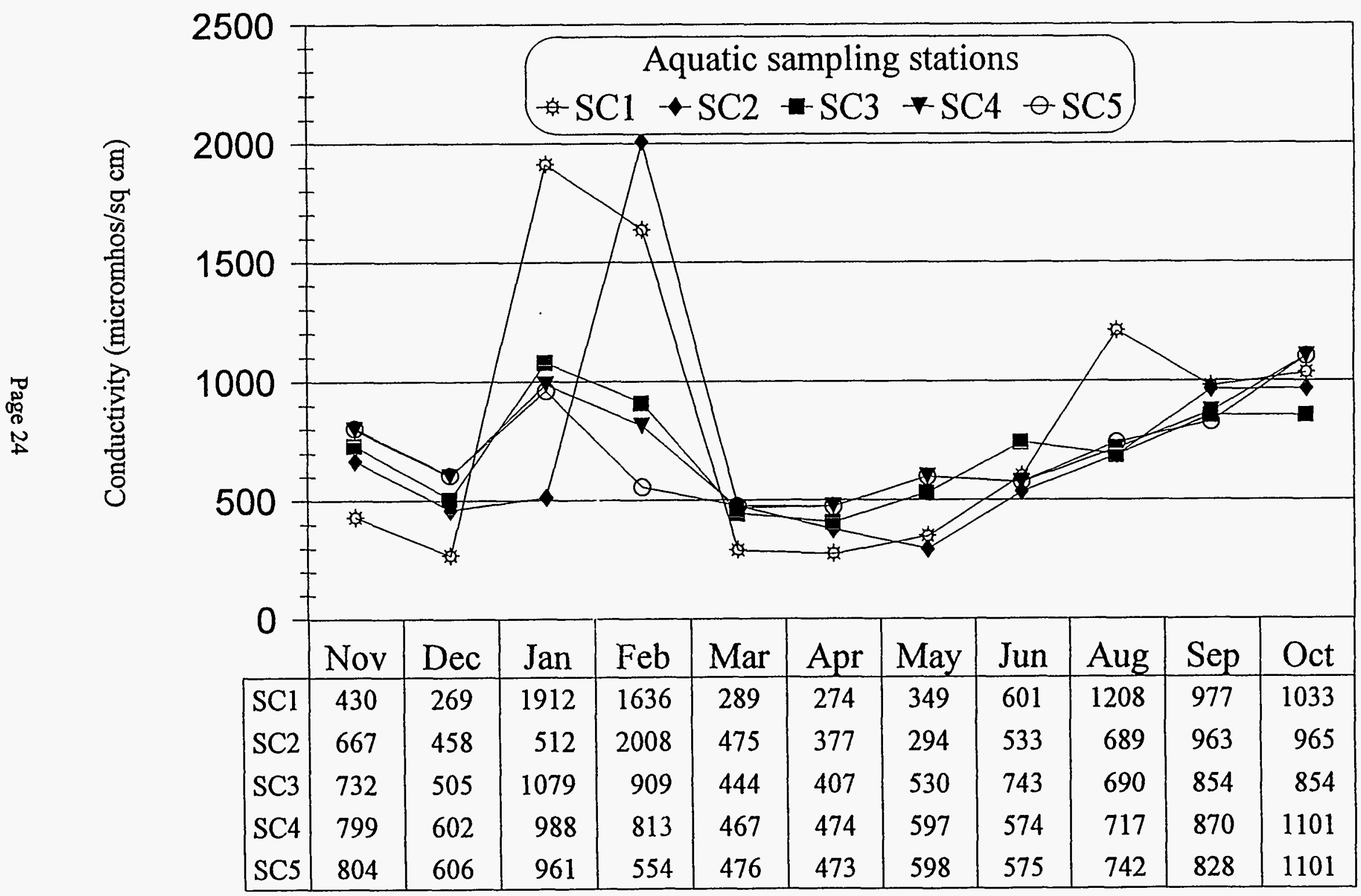

Figure 10. Monthly conductivity in Sandia Canyon, November 1993 through Ocotber 1994. 


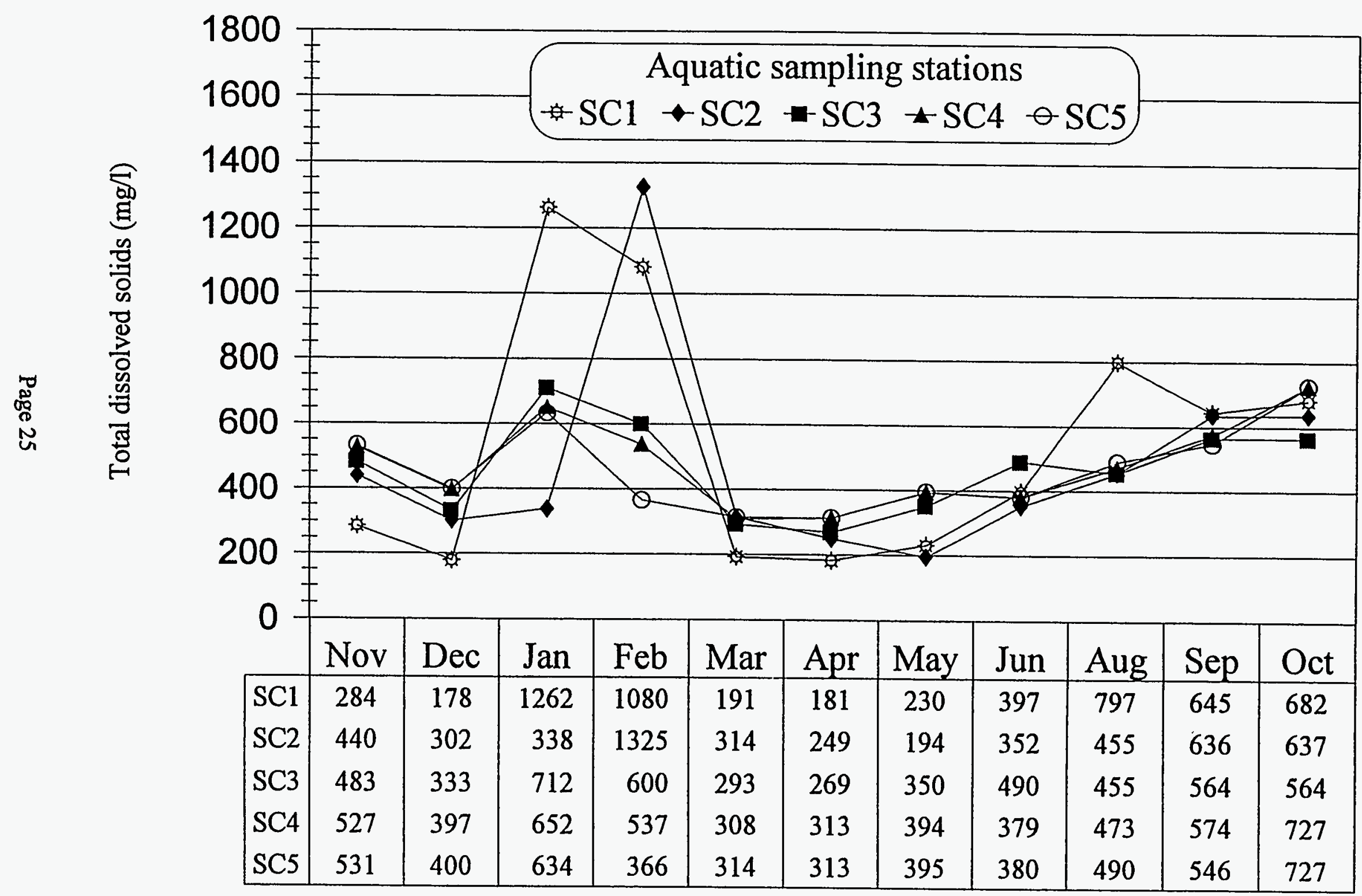

Figure 11. Monthly total dissolved solids in Sandia Canyon, November 1993 through Ocotber 1994. 


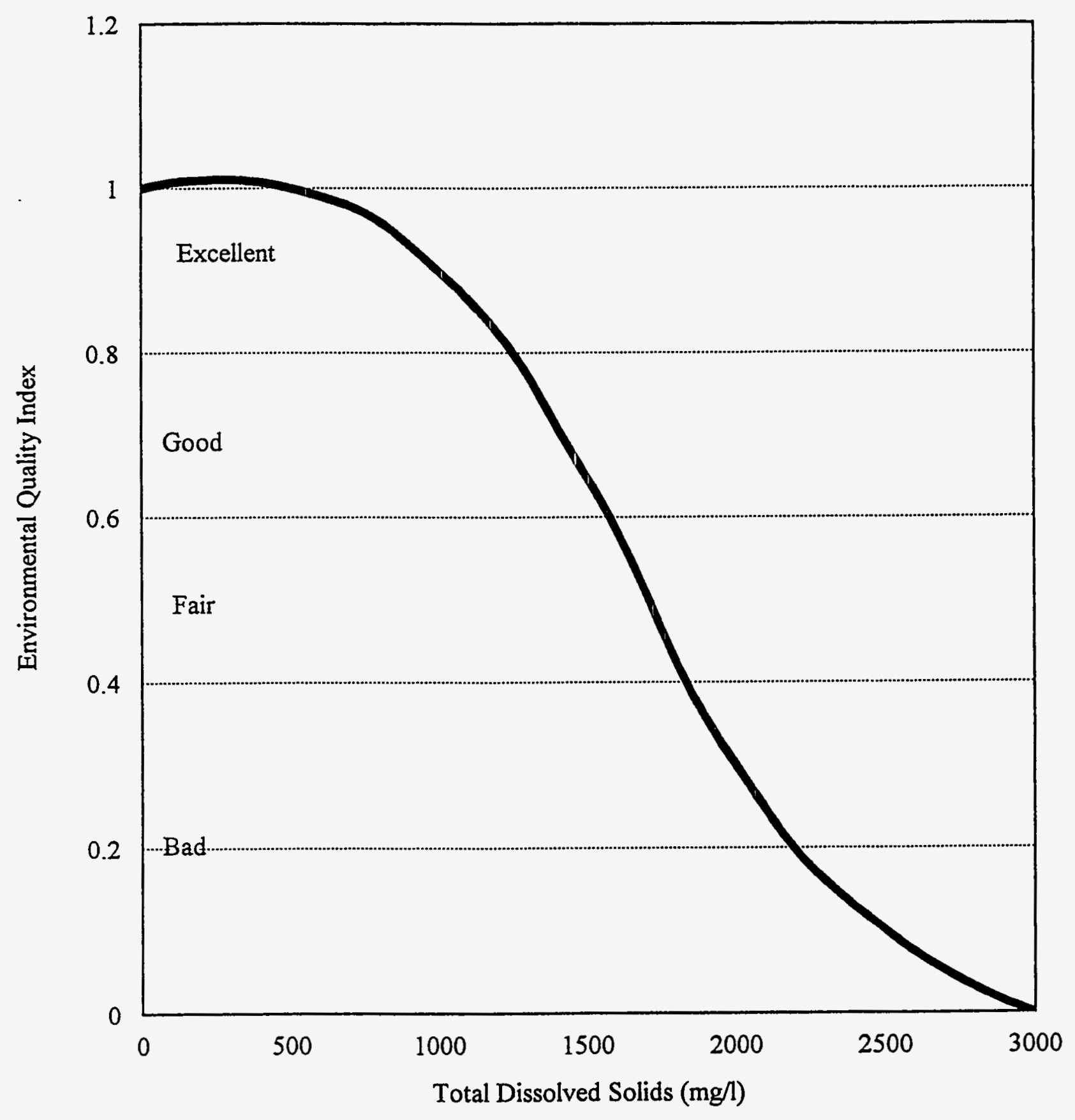

Fig. 12. TDS (mg/l) versus an Environmental Quality Index (Battelle, 1972). 


\subsection{Aquatic Macroinvertebrate Analysis}

\subsubsection{Total Numbers and Taxa}

A total of 3,562 macroinvertebrates of 48 taxa (Appendix A) were collected, identified, and analyzed from November 1993 to October 1994. The previous year's sampling collected 3,030 individuals of 36 taxa, but the difference between the two year totals is attributable to natural variation and more discriminating identifications, especially of the Coleoptera (beetles). Appendix B lists the aquatic macroinvertebrates previously collected in Los Alamos County and its surrounding watersheds for comparison. Fig. 13 displays the numbers of individual macroinvertebrates collected at each sampling station. The greatest number of invertebrates (57\% of the total) were collected at SC3. Of the other four stations, $\mathrm{SC1}$ and $\mathrm{SC} 2$ had significantly reduced numbers of aquatic macroinvertebrates when compared to SC4 and SC5.

The number of taxa found at each station is shown in Fig. 14. Most of the macroinvertebrates collected (59\%) occurred at SC3; and most (58\%) of those collected at this station were ostracods and copepods, orders of opportunistic crustaceans known to experience periodic population explosions. Although SC2 had fewer taxa than the other stations (only 15 compared to an average of 22), the taxa were much more evenly distributed at the sampling stations than in the previous year. This may be due to sedimentation from the upper canyon moving down the stream channel and degrading the habitat there.

\subsubsection{Population Distributions}

Population distributions and average number of aquatic macroinvertebrates varied greatly along the length of the stream. Population distributions reflect community stability by examining monthly variances. One method is to compare the number of macroinvertebrates collected at a station during its most populous months to its yearly total. More than half of the macroinvertebrates found at the three upstream stations were collected during only two months (Table 2), indicating that these stations had unstable 


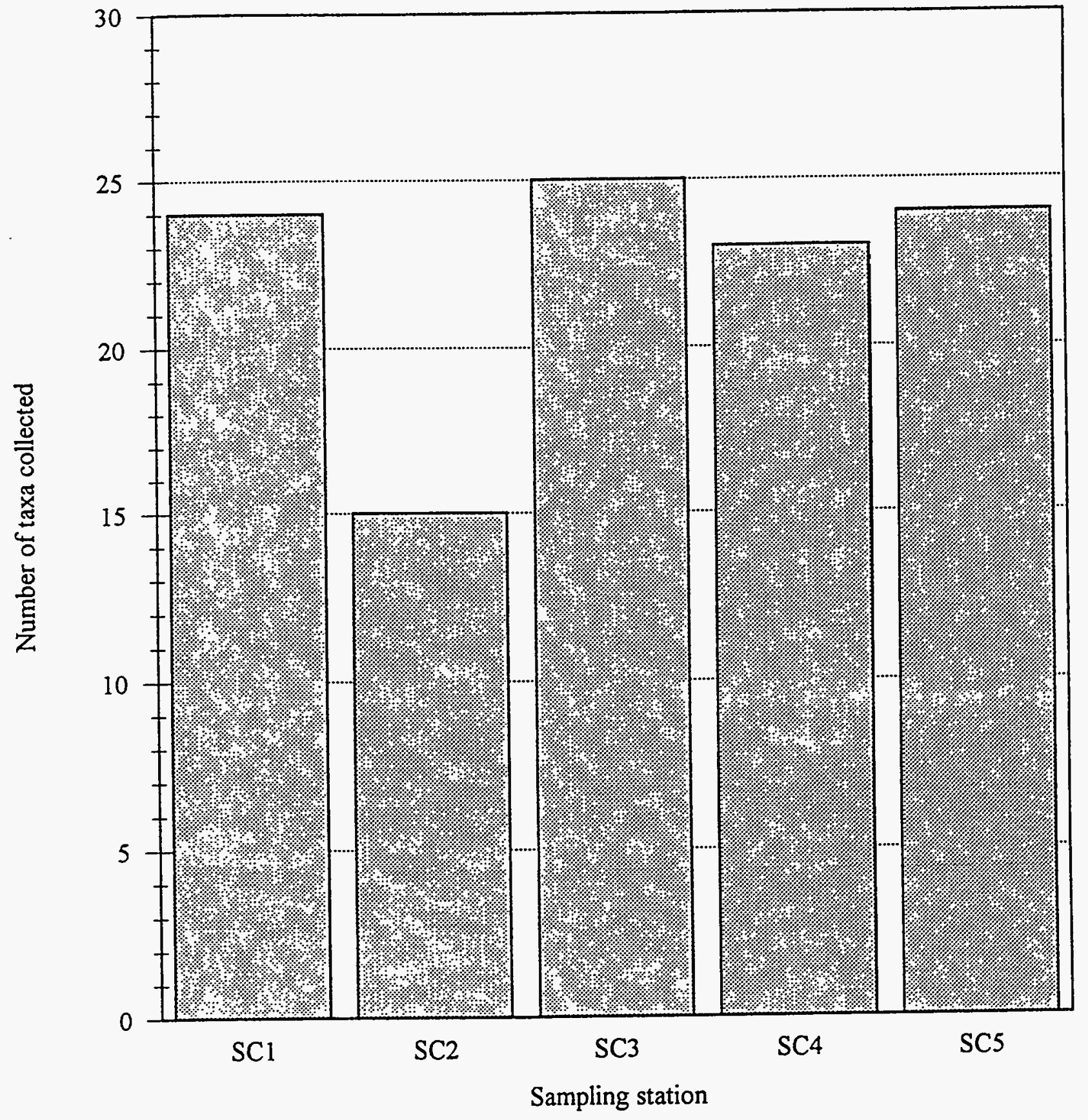

Figure 13. Number of taxa collected in Sandia Canyon, November 1993 through October 1994. 
Number of individuals collected

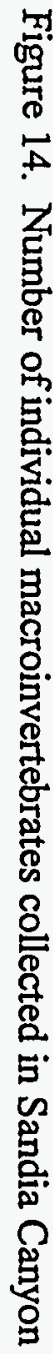

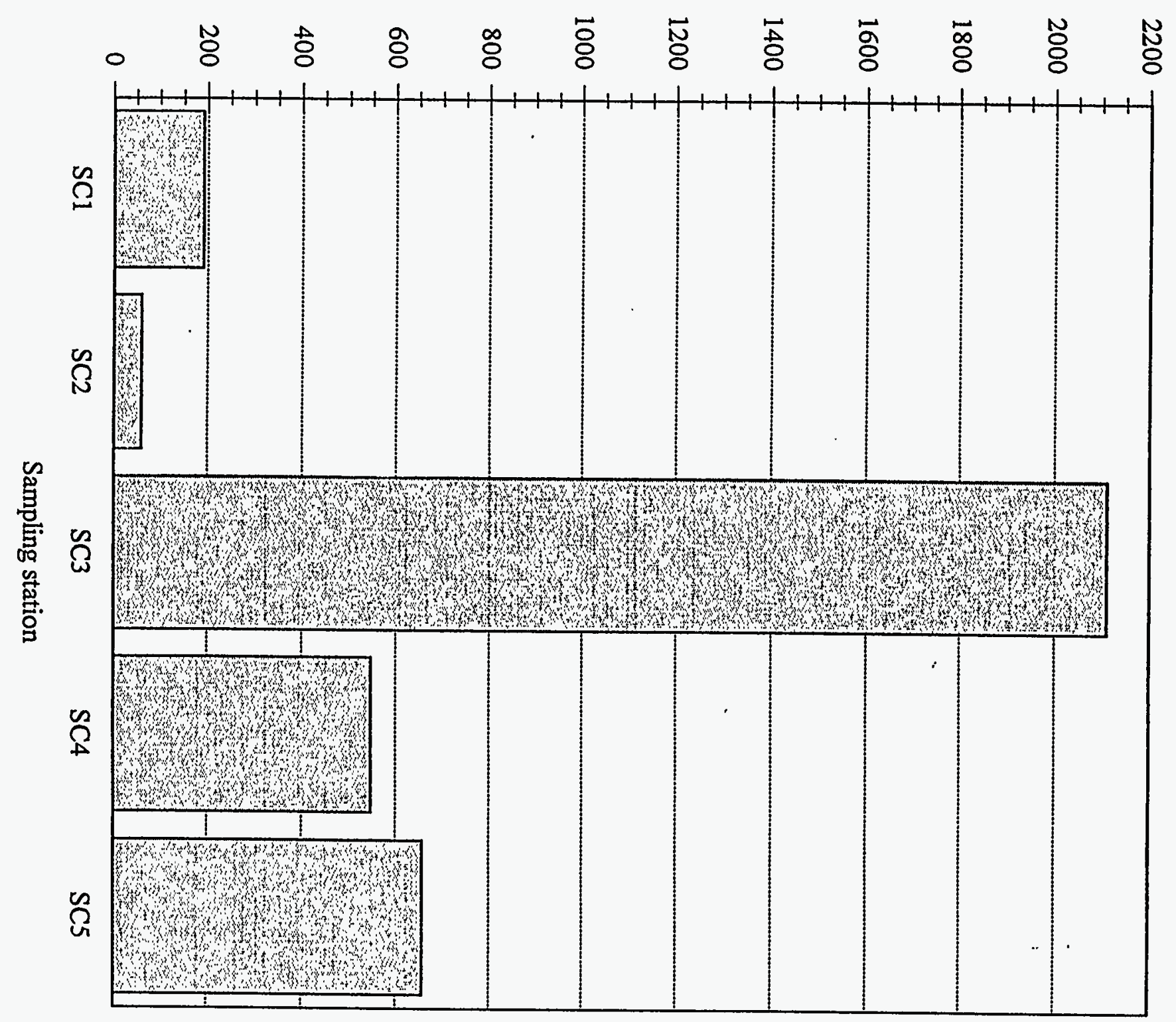


communties. The lower two stations had more even macroinvertebrate distributions, although they were only sampled 11 times (ice prevented taking samples at SC4 and SC5 during February 1994).

Table 2. Monthly Average, Total, and Two-Most-Populous-Month Numbers of Macroinvertebrates for Sandia Canyon Sampling Stations, November 1993 through October 1994.

\begin{tabular}{|c|c|c|c|c|}
\hline Station & $\begin{array}{c}\text { Average Number } \\
\text { Collected }\end{array}$ & $\begin{array}{c}\text { Number Collected } \\
\text { in TMPM }\end{array}$ & $\begin{array}{c}\text { Total Number } \\
\text { Collected }\end{array}$ & $\begin{array}{c}\text { TMPM }^{\star} / \text { Total } \\
\text { Percentage }\end{array}$ \\
\hline 1 & 15.8 & 163 & 190 & 85.8 \\
\hline 2 & 5.1 & 41 & 61 & 67.2 \\
\hline 3 & 175.8 & 1275 & 2110 & 60.4 \\
\hline 4 & 49.6 & 251 & 546 & 46.0 \\
\hline 5 & 68.7 & 341 & 756 & 45.1 \\
\hline
\end{tabular}

* Two-Most-Populous-Months

Another measure of population distributions is the determination of the number of months that no aquatic invertebrates were collected at a sampling station. No macroinvertebrates were found at $\mathrm{SC} 1$ on $33 \%$ of the sampling dates; and none were collected at SC2 on $50 \%$ of the sampling dates. In contrast, macroinvertebrates were collected at $\mathrm{SC} 3, \mathrm{SC} 4$, and $\mathrm{SC} 5$ every time a sample was taken.

\subsubsection{Tolerance Quotients}

Tolerance quotients for each taxa found in Sandia Canyon are listed in Appendix C. The computed yearly CTQs for each sampling station are very similiar at all sampling stations (Table 3). The table indicates that $\mathrm{SC1}$ supported the most sensitive communtity of aquatic macroinvertebrates. However, its low yearly CTQ value is solely due to the large numbers of Baetid mayflies (126 individuals of the genus Callibaetis; tolerance quotient of 72) collected at $\mathrm{SC} 1$ in September and October.

Table 3. Yearly Community Tolerance Quotients for Sandia Canyon Sampling Stations, November 1993 through October 1994.

\begin{tabular}{|c|c|c|c|}
\hline Station & Individuals & Tolerance Sums & CTQ \\
\hline 1 & 188 & 15072 & 80.2 \\
\hline 2 & 59 & 5832 & 98.8 \\
\hline
\end{tabular}




\begin{tabular}{|c|c|c|c|}
\hline 3 & 2110 & 207432 & 98.3 \\
\hline 4 & 546 & 48348 & 88.6 \\
\hline 5 & 756 & 73224 & 96.9 \\
\hline
\end{tabular}

\subsubsection{Community Structure}

A natural aquatic ecosystem has a balanced community occupying all available microhabitats and utilizing a variety of food resources. Appendix D lists the habit, or mode of existence, for most of the aquatic insects collected in this study (taxonomic difficulties prohibited a more thorough breakdown of the dipteran family Chironomidae). All stations contained representative swimmers, clingers, climbers, and burrowers. In 1993, very few clingers, sprawlers, or climbers were found at the upper stations in comparison with the lower stations. The difference between the two years is attributable to the presence of Odonata (damselfly and dragonfly) larvae at the upper stations in 1994.

Aquatic insects base their selection of food particles more on particle size than origin. Thus, the familiar trophic (feeding) categories of herbivore, carnivore, and omnivore have little application to aquatic macroinvertebrates. To more accurately describe the trophic relations of aquatic insects, a series of functional feeding groups or trophic categories has been developed (Merritt and Cummins 1984). These categories (Table 4) are determined by feeding mechanism more than food origin.

Table 4. Chief Functional Feeding Groups of Aquatic Insects.

\begin{tabular}{|c|c|}
\hline Functional Group & Dominant Food \\
\hline Collectors & Fine particulate organic matter \\
\hline Shredders & Coarse particulate organic matter \\
\hline Scrapers & Attached algae and associated material \\
\hline Predators & Engulfers or piercers feeding on living animal tissue \\
\hline Piercers & Pierce plant cells or tissues and suck out fluids \\
\hline
\end{tabular}

A natural ecosystem usually contains varied representatives of the primary functional feeding groups. Appendix $\mathrm{E}$ lists the functional feeding group for most of the insects collected during this study. Upper Sandia Canyon does not support a large algal 
population, and scrapers were therefore not abundant at any sampling station. Collectors and predators were found at all stations. Only one individual of each of the two piercer taxa found in Sandia were collected. Only two shredder taxa were collected and almost all of these (27 of 28) occurred at SC5. In terms of functional feeding groups,all five sampling stations were similar with SC5 having slightly more diversity. This contrasts with 1993 data that reported much more complex communties at the downstream sites. The difference is probably due to differences in sampling at the SC4 and SC5 sites and downstream habitat degradation, primarily due to sedimentation.

\subsubsection{Biodiversity}

Wilhm's biodiversity indices (Wilhm 1967) were calculated monthly for each sample station from November 1993 to October 1994 (Fig. 15). Small high-elevation streams tend to have low taxa diversity overall (Hilsenhoff 1977), and all values recorded were less than 3.0. However, when the differences between yearly biodiversity averages (Table 5) appear to be significant. The lowest yearly biodiversity index values were recorded at the upstream stations; the highest values were recorded at the downstream stations.

Table 5. Yearly Averages of Wilhm's Biodiveristy Values for Sandia Canyon Sampling Stations, November 1993 through October 1994.

\begin{tabular}{|c|c|}
\hline Station & Biodiversity Value \\
\hline 1 & 0.89 \\
\hline 2 & 0.66 \\
\hline 3 & 1.08 \\
\hline 4 & 1.48 \\
\hline 5 & 1.62 \\
\hline
\end{tabular}

\section{CONCLUSIONS}

The great majority of physical and chemical measures taken in Sandia Canyon are within New Mexico standards for coldwater fisheries (Note: water temperatures were evaluated according to state standards for warmwater fisheries). Several upstream highconductivity and TDS readings are due to parking lot runoff, which carried road salt into 


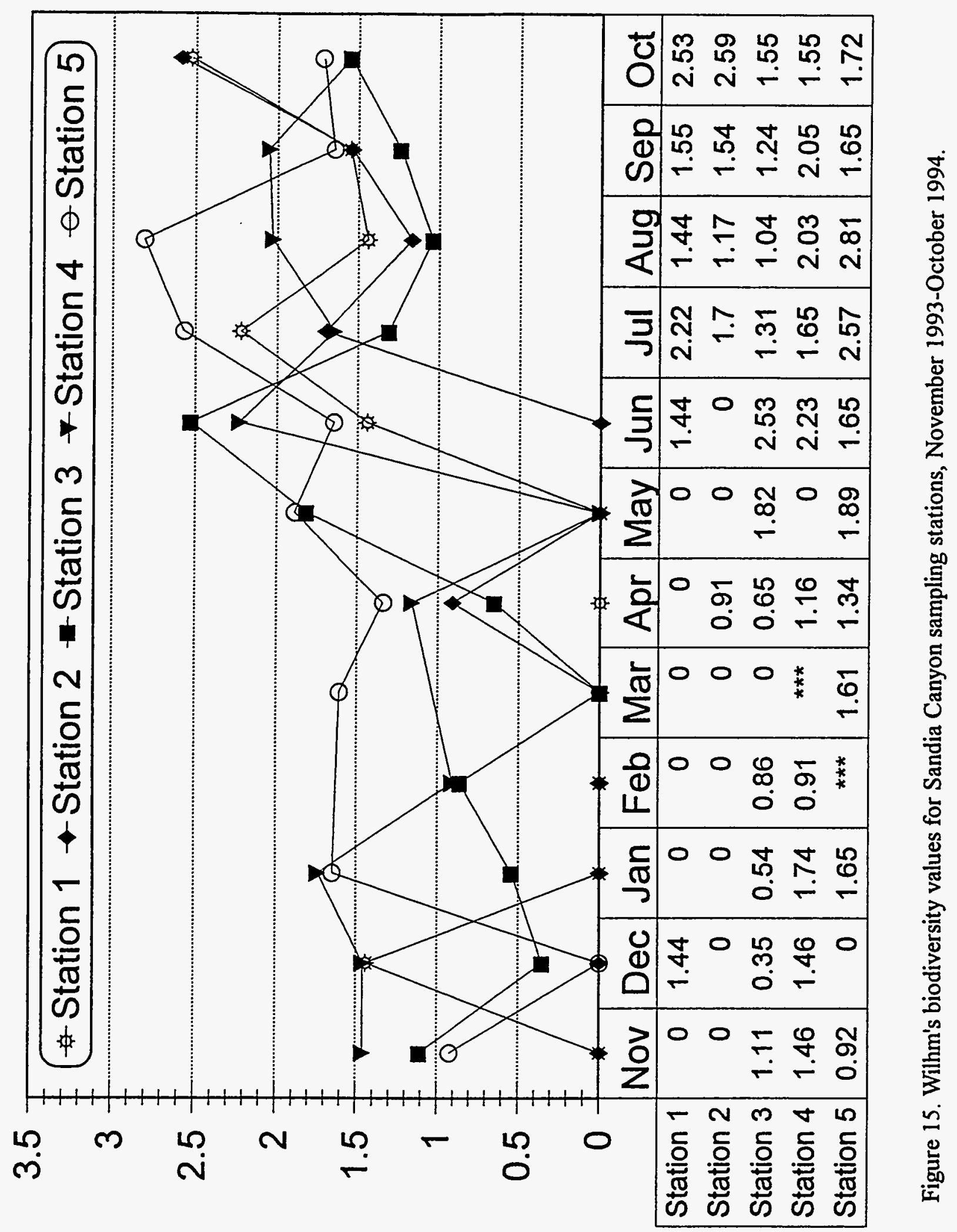

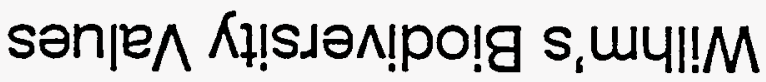


the stream during winter months. Low $\mathrm{pH}$ and $\mathrm{DO}$ readings at the middle stream are ascribed to the effects of natural vegetative decomposition. Dissolved oxygen concentrations at the upstream stations were in Batelle's excellent range, suggesting that no significant amounts of organic pollutants are entering the stream. However, the high temperatures and occasional high-pH values at the upper stations are attributable to effluent discharges. Elevated chlorine levels from a sanitary outfall discharging above SC2 are the probable cause for that station's low macroinvertebrate numbers and diversity.

The two upstream sampling stations have low numbers of macroinvertebrates, reduced biodiversity, and unstable macroinvertebrate communities. These depauperate conditions are due to habitat degradation resulting from restricted colonization, sedimentation, channelization, scoured substrates, severely fluctuating water and temperature levels, and effluent discharges. The middle sampling station had high numbers of macroinvertebrates, intermediate biodiversity, and a more stable macroinverteberate community. In contrast, the downstream two sampling stations have intermediate numbers of invertebrates, increased biodiversity, and the most stable macroinvertebrate communities. These downstream communities and taxa more closely resemble those of natural streams in the area, suggesting a zone of recovery where upstream effluent discharges and habitat impoverishment are mitigated by the intervening cattail marsh. However, these communities are not as robust (lower biodiversities and less complex community structures) as previously reported, possibly due to effects of effluents and sedimentation reaching further downstream. 


\section{ACKNOWLEDGMENTS}

This study was overseen by Kathryn Bennett, project ecologist for the Ecological Studies Team in the Environmental Assessments and Resource Evaluations section of the Environmental Protection Group (ESH-20) at LANL.

Field and laboratory personnel included Saul Cross (field leader and aquatic entomologist), Dan Dunham (botanist), Tom Gonzales (UGS), David Keller (GRA), and Leonard Sandoval (UGS). Saul Cross identified all aquatic macroinvertebrates, analyzed the data, and compiled the manuscript. Dr. Gerald $Z$. Jacobi of New Mexico Highlands University confirmed the identifications and reviewed the report. 


\section{REFERENCES}

Anderson, N. H., and Wallace, J. B., "Habitat, Life History, and Behavioral Adaptations of Aquatic Insects, " pp. 38-58 in An Introduction to the Aquatic Insects of North America, second edition, edited by R. W. Merritt and K. W. Cummins, Kendall/Hunt Publishing Company, Dubuque, Iowa (1984).

Battelle, Columbus Laboratories, "Environmental Evaluation System for Water Resources Planning" Bureau of Reclamation, U.S. Department of Interior, Contract Number 14-06D-1782, Columbus Ohio (1972).

Baumann, R.W., Gaufin, A.R., and Surdick, R.F., The Stoneflies (Plecoptera) of the Rocky Mountains, American Entomological Society at the Academy of Natural Sciences, Philadelphia, Pennsylvania (1977).

Bell, Henry, "Effect of Low pH on the Survival and Emergence of Aquatic Insects" in Water Research, Vol. 5, pp. 313-319, Pergamon Press (1971).

Bennett, Kathryn, "Aquatic Macroinvertebrates and Water Quality Monitoring of Sandia Canyon," Los Alamos National Laboratory report, LA-12738 (1994).

Bowen, B.M., "Los Alamos Climatology," Los Alamos National Laboratory report, LA-11735-MS (1990).

Canter, L.W., and Hill, L.G., Handbook of Variables for Environmental Impact Assessment, Ann Arbor Science Publishers, Inc., Michigan (1979).

Cowardin, L.M., Carter, V., Glet, F.C., and E.T. LaRoe, Classification of Wetlands and Deep Water Habitats of the United States, U.S. Fish and Wildlife Service, Washington, D.C., Publication No. FWS/OBS-79/31 (1979).

Cross, Saul, "Aquatic Macroinvertebrates and Water Quality of Sandia Canyon, Los Alamos National Laboratory", Los Alamos National Laboratory report, LA-12734-SR (1994).

Cummins, Kenneth W. and Merritt, Richard W., "Ecology and Distribution of Aquatic Insects," pp. 59-65 in An Introduction to the Aquatic Insects of North America, second edition, edited by R. W. Merritt and K. W. Cummins, Kendall/Hunt Publishing Company, Dubuque, Iowa (1984).

Emunds, G.F., Jensen, S.L., and Berner, L., The Mayflies of North and Central America, University of Minnesota Press, Minneapolis, Minnesota (1976). 
Eriksen, Clyde, Vincent H. Resh, Steven S. Bailing, and Gary A. Lamberti, "Aquatic Insect Respiration," pp. 27-37 in An Introduction to the Aquatic Insects of North America, second edition, edited by R. W. Merritt and K. W. Cummins, Kendall/Hunt Publishing Company, Dubuque, Iowa (1984).

Gaufin, A.R., Clubb, Robert, and Newell, Robert, "Studies on the Tolerance of Aquatic Insects to Low Oxygen Concentrations," Great Basin Naturalist, Vol. 34, No. 1, pp. 45-59 (1974).

Gaufin, A.R. and Tarzwell, C.M., "Aquatic Macro-Invertebrate Communities as Indicators of Organic Pollution in Lytle Creek," Sewage and Industrial Waste, Vol. 28, No. 7, pp. 906-924 (1956).

Hilsenhoff, W., "The Use of Arthropods to Evaluate Water Quality of Streams", Technical Bulletin No. 100, Department of Natural Resources, Madison, Wisconsin 53707 (1977).

Hill, B.H., Dynamics of Wetlands: New Approaches to Assessing Wetland Structure and Function, a Journal of the North American Benthological Society Technical Information Workbook (1994).

Intergovernmental Task Force on Monitoring Water Quality, Ambient Water-Quality Monitoring in the United States: First Year Review, Evaluation, and Recommendations, report to the Office of Management and Budget (1992).

Intergovernmental Task Force on Monitoring Water Quality, The Strategy for Improving Wter-Quality Monitoring in the United States (Draft 1994).

Jacobi, Gerald Z., "Benthic Macroinvertebrate Assessment of Several Small Streams -Implementation of the 1987 Santa Fe National Forest Plan", U.S. Forest Service, Santa Fe National Forest, Santa Fe, New Mexico, Contract \# 43-8379-0-0327 (1989).

Jacobi, Gerald Z., "Benthic Macroinvertebrate Assessment of Several Small Streams -Implementation of the 1987 Santa Fe National Forest Plan, second survey", U.S. Forest Service, Santa Fe National Forest, Santa Fe, New Mexico, Contract \# 43-8379-0-0327 (1990).

Jacobi, Gerald Z., "Benthic Macroinvertebrate Assessment of Several Small Streams -Implementation of the 1987 Santa Fe National Forest Plan, 1990 survey", U.S. Forest Service, Santa Fe National Forest, Santa Fe, New Mexico, Contract \# 43-8379-0-0327 (1992).

Karr, J.R., "Biological Integrity: a Long-Neglected Aspect of Water Resource Management", Ecological Applications, 1:66-84 (1991).

Kubic, C, "Multi-Meida Compliance Investigation”, Department of Energy report (1993). 
LANL, Environmental Surveillance at Los Alamos During 1988, Los Alamos National Laboratory report, LA-11628-MS (1988).

LANL, Environmental Surveillance at Los Alamos During 1989, Los Alamos National Laboratory report, LA-12000-ENV (1990).

Lehmkuhl, D. M., "Environmental Disturbance and Life Histories: Principles and Examples," Journal of the Fisheries Research Board of Canada, Vol. 36, pp. 329-334 (1979).

McCafferty, W. Patrick, Aquatic Entomology, Jones and Bartlett Puslishers, Inc., Boston, Mass. (1981).

Merritt, R. W. and Cummins, K. W., Eds., An Introduction to the Aquatic Insects of North America, second edition, Kendall/Hunt Publishing Company, Dubuque, Iowa (1984).

Nebeker, A.V., "Effect of Low Oxygen Concentration on Survival and Emergence of Aquatic Insects." Trans. Amer. Fish Soc., No. 4, pp. 675-679 (1972).

Pennak, R.W., Fresh-Water Invertebrates of the United States, second ed., John Wiley \& Sons, New York, New York (1978).

Rosenberg, D.M., H.V. Danks, and D.M. Lehmkuhl, "Importance of Insects in Environmental Impact Assessments," Environmental Management, Vol. 10, No. 6, pp. 773-783 (1986).

Schwenneker, Bruce W. and Ronald A. Hellenthal, "Sampling Considerations in Using Stream Insects for Monitoring Water Quality," Environmental Entomology, Vol. 13, No. 3 (1984).

State of New Mexico, "Standards for Interstate and Intrastate Streams", New Mexico Water Quality Control Commission, Santa Fe, New Mexico (1995).

Weber, C.I., "Biological Field and Laboratory Methods for Measuring the Quality of Surface Waters and Effluents," National Environmental Research Center, Cincinnati, Ohio, PB-227-183, pp. 70-109 (1973).

Wiggins, G.B., Larvae of the North American Caddisfly Genera (Trichoptera), University of Toronto Press (1978).

Wilhm, J.L., "Comparison of Some Diversity Indices Applied to Populations of Benthic Macroinvertebrate in a Stream Receiving Organic Waste," Journal WPCF Vol. 39, No. 10, Part 1, pp. 1673-1683 (1967). 
Winget, R.N., and Magnum, F.A., Biotic Condition Index: Integrated Biological, Physical, and Chemical Stream Parameters for Management, Intermountain Region, U.S. Department of Agriculture, Forest Service, Ogden, Utah. 


\section{APPENDIX A}

\section{Macroinvertebrate Taxa Collected in Upper Sandia Canyon, November 1993 through October 1994.}

Insects:

\begin{tabular}{|c|c|c|c|}
\hline Order & Family & Genus (species) & Station \\
\hline \multirow[t]{3}{*}{ Ephemeroptera } & Baetidae & Baetis & $1,2,3,4,5$ \\
\hline & Baetidae & Callibaetis & $1,2,3,4,5$ \\
\hline & Tricorythidae & Tricorythodes (minutus) & $1,3,4,5$ \\
\hline \multirow[t]{11}{*}{ Odonata } & Aeshnidae & Aeshna & 5 \\
\hline & Aeshnidae & Anax & $1,2,3,4,5$ \\
\hline & Aeshnidae & Boyeria & $1,3,4,5$ \\
\hline & Aeshnidae & & 2 \\
\hline & Coenagrionidae & Argia & $1,2,3,4,5$ \\
\hline & Coenagrionidae & Enallagma & 1 \\
\hline & Coenagrionidae & Ischmura & 3 \\
\hline & Coenagrionidae & Zonagrion & 3 \\
\hline & Coenagrionidae & & 3,5 \\
\hline & Cordulegastridae & Cordulegaster & 4 \\
\hline & Lestidae & Archilestes & 1,3 \\
\hline \multirow[t]{5}{*}{ Hemiptera } & Corixidae & & 2 \\
\hline & Gerridae & Gerris & $1,4,5$ \\
\hline & Gerridae & Trepobates & $1,4,5$ \\
\hline & Notonectidae & Notonecta & 3 \\
\hline & Veliidae & Rhagovelia & 2 \\
\hline \multirow[t]{3}{*}{ Trichoptera } & Hydropsychidae & Hydropsyche & 4,5 \\
\hline & Hydroptilidae & Hydroptila & 4 \\
\hline & Limnephilidae & Hesperophylax & 4,5 \\
\hline \multirow[t]{10}{*}{ Coleoptera } & Dryopidae adult & Helichus & 4,5 \\
\hline & Dytiscidae & Hydaticus & 4 \\
\hline & Dytiscidae & Hydroporus & 4 \\
\hline & Dytiscidae & Hygrotus & 5 \\
\hline & Dytiscidae & & $2,3,4,5$ \\
\hline & Dytscidae adult & $A$ & 2,5 \\
\hline & Dytiscidae adult & $B$ & 3,4 \\
\hline & Dytiscidae adult & $C$ & 1 \\
\hline & Dytiscidae adult & & 3,4 \\
\hline & Hydrophilidae & Ametor & 1 \\
\hline \multirow[t]{3}{*}{ Diptera } & Ceratopogonidae & Bezzia & 1,5 \\
\hline & Chironomidae & $A$ & $1,2,3,4,5$ \\
\hline & Chironomidae & $B$ & 3,5 \\
\hline
\end{tabular}




\begin{tabular}{|l|l|l|l|}
\hline Order & \multicolumn{1}{|c|}{ Family } & \multicolumn{1}{|c|}{ Genus (species) } & Station \\
\hline & Chironomidae & C & $1,3,4,5$ \\
\hline & Chironomidae & G & 3,5 \\
\hline & Chironomidae & pupae $P B$ & $1,2,3,4$ \\
\hline & Chironomidae & pupae PC & $1,2,3,5$ \\
\hline & Culicidae & & 3 \\
\hline & Empididae & Hemerodromia & 2,5 \\
\hline & Empididae & Oreogeton & 1 \\
\hline & Ephydridae & Brachydeutera & 1,3 \\
\hline & Ephydridae & pupa & 2 \\
\hline & Heleidae & & 3 \\
\hline & Muscidae & Limnophora & 2,4 \\
\hline & Psychodidae & Maruina & 1 \\
\hline & Psychodidae & pupae & 1 \\
\hline & Simulidae & & $2,3,5$ \\
\hline & Simulidae & pupae & 4 \\
\hline & Tabanidae & Tabanus & 1 \\
\hline & Tabanidae & & 2 \\
\hline & Tipulidae & Dicranota & 1 \\
\hline & Tipulidae & Tipula B & 1 \\
\hline
\end{tabular}

\section{Non-insects:}

\begin{tabular}{|l|l|l|l|l|}
\hline \multicolumn{1}{|c|}{ Phylum } & \multicolumn{1}{|c|}{ Class } & \multicolumn{1}{|c|}{$\begin{array}{c}\text { Order or } \\
\text { Sub-Class }\end{array}$} & \multicolumn{1}{|c|}{ Family } & \multicolumn{1}{c|}{$\begin{array}{c}\text { Sampling } \\
\text { Station }\end{array}$} \\
\hline Annelida & Oligochaeta & & Lumbriculidae & $1,2,3,4,5$ \\
\hline & & & Naididae & 3 \\
\hline Arthropoda & Crustacea & Copepoda & & 3 \\
\hline & Crustacea & Ostracoda & Candonidae & $2,3,4,5$ \\
\hline & Crustacea & Ostracoda & Cyprididae & $1,3,4,5$ \\
\hline Mollusca & Gastropoda & Basommatophora & $\begin{array}{l}\text { Lymnaeidae, } \\
\text { Lymnaea }\end{array}$ & 5 \\
\hline & Gastropoda & Basommatophora & $\begin{array}{l}\text { Physidae, } \\
\text { Physa }\end{array}$ & 3 \\
\hline Platyhelminthes & Turbellaria & & & 1 \\
\hline
\end{tabular}




\section{APPENDIX B}

Aquatic Invertebrates Collected

in Los Alamos County and Adjacent Watersheds

$\left(^{*}=\right.$ life stage not known, all specimens are larval unless otherwise noted)

Insects:

\begin{tabular}{|c|c|c|c|c|}
\hline ORDER & FAMULY & GENUS & SPECIES & $\underset{\star \star \star}{\text { LOCATION }}$ \\
\hline \multirow{32}{*}{$\begin{array}{l}\text { Plecoptera } \\
\text { (Stoneflies) }\end{array}$} & Capniidae & Capnia & & $\mathrm{F}$ \\
\hline & Capniidae & & & $\mathrm{F}$ \\
\hline & Chloroperlidae & Chloroperla & & $\mathrm{F}$ \\
\hline & Chloroperlidae & Paraperla & frontalis & $\mathrm{G}, \mathrm{L}$ \\
\hline & Chloroperlidae & Paraperla & & $F$ \\
\hline & Chloroperlidae & Sweltsa & coloradensis & $\mathrm{F}$ \\
\hline & Chloroperlidae & Sweltsa a & $\operatorname{lamba}$ & $\mathrm{F}$ \\
\hline & Chloroperlidae & Sweltsa & & $F, G$ \\
\hline & Chloroperlidae & Suwallia & & $\mathrm{G}, \mathrm{L}$ \\
\hline & Chloroperlidae & & & $\mathrm{F}, \mathrm{G}, \mathrm{L}, \mathrm{SG}$ \\
\hline & Leuctridae & Paraleuctra & vershina & $\mathrm{F}$ \\
\hline & Nemouridae & Amphinemura & & $\mathrm{F}, \mathrm{G}$ \\
\hline & Nemouridae & Amphinemura & banksi & F,G,L,P,SG \\
\hline & Nemouridae & Malenka & coloradensis & $\mathrm{F}$ \\
\hline & Nemouridae & Malenka & & $\mathrm{G}, \mathrm{L}$ \\
\hline & Nemouridae & Nemoura & & $\mathrm{F}$ \\
\hline & Nemouridae & Podmosta & delicatula & $\mathrm{G}$ \\
\hline & Nemouridae & Zapada & cinctipes & $F$ \\
\hline & Nemouridae & Zapada & frigida & $\mathrm{I}$ \\
\hline & Perlidae & Acroneuria & abnormis & $\mathrm{F}$ \\
\hline & Perlidae & Hesperoperla & pacifica & $\mathrm{F}, \mathrm{L}, \mathrm{SG}$ \\
\hline & Perlodidae & Cultus & aestivalis & GL \\
\hline & Perlodidae & Cultus & & $\mathrm{G}$ \\
\hline & Perlodidae & Isoperla & fulva & $\mathrm{F}$ \\
\hline & Perlodidae & Isoperla & $\begin{array}{l}\text { quinquepunct } \\
\text { ata }\end{array}$ & $\mathrm{F}$ \\
\hline & Perlodidae & Isoperla & & $\mathrm{F}, \mathrm{G}, \mathrm{L}, \mathrm{S}$ \\
\hline & Perlodidae & Kogotus & modestus & $\mathrm{G}, \mathrm{L}$ \\
\hline & Perlodidae & Skwala & parallela & $\mathrm{G}$ \\
\hline & Pteronarcyidae & Pteronarcella & badia & $\mathrm{F}, \mathrm{G}$ \\
\hline & Pteronarcyidae & Pteronarcella & & $\mathrm{F}$ \\
\hline & Pteronarcyidae & Pteronarcys & californica & $\mathrm{G}$ \\
\hline & Pteronarcyidae & Pteronarcys & & $\mathrm{G}$ \\
\hline
\end{tabular}




\begin{tabular}{|c|c|c|c|c|}
\hline ORDER & FAMULY & GENUS & SPECIES & $\underset{* *}{\text { LOCATION }}$ \\
\hline & Taeniopterygidae & Taenionema & & F \\
\hline \multirow{24}{*}{$\begin{array}{l}\text { Ephemeroptera } \\
\text { (Mayflies) }\end{array}$} & Baetidae & Baetis & bicaudata & $\bar{F}$ \\
\hline & Baetidae & Baetis & insignificans & F \\
\hline & Baetidae & Baetis & tricaudatus & $\begin{array}{l}\text { A,D,F,G,L, } \\
\text { PS,S }\end{array}$ \\
\hline & Baetidae & Baetis & & $\begin{array}{l}\text { A,C,F,G,H,L, } \\
\text { P,PS,S,SG, } \\
128\end{array}$ \\
\hline & Baetidae & Callibaetis & & $\begin{array}{l}\text { G,L,P,PS,S,4 } \\
8\end{array}$ \\
\hline & Ephemerellidae & Drunella & coloradensis & G,L \\
\hline & Ephemerellidae & Drunella & doddsi & $\mathbf{F , G}$ \\
\hline & Ephemerellidae & Drunella & $\begin{array}{l}\text { grandis } \\
\text { grandis }\end{array}$ & F,G \\
\hline & Ephemerellidae & Ephemerella & inermis & $\mathrm{F}, \mathrm{G}, \mathrm{L}$ \\
\hline & Ephemerellidae & Ephemerella & infrequens & $\overline{F, G}$ \\
\hline & Ephemerellidae & Ephemerella & & $\mathrm{F}$ \\
\hline & Heptageniidae & Cinygmula & & F,G,L \\
\hline & Heptageniidae & Epeorus & longimamus & $\mathrm{F}, \mathrm{G}, \mathrm{L}$ \\
\hline & Heptageniidae & Epeorus & & $\mathrm{F}, \mathrm{G}, \mathrm{L}$ \\
\hline & Heptageniidae & Heptagenia & & $\mathrm{G}$ \\
\hline & Heptageniidae & Nixe & simplicoides & $\bar{L}$ \\
\hline & Heptageniidae & Rhithrogena & & $\bar{F}$ \\
\hline & Leptophlebiidae & Paraleptophlebia & & $\mathrm{F}, \mathrm{G}, \mathrm{L}$ \\
\hline & Siphlonuridae & Ameletus & & F,G,L,S,SG \\
\hline & Siphlonuridae & Siphlonurus & occidentalis & $\mathrm{F}, \mathrm{L}$ \\
\hline & Siphlonuridae & Siphlomurus & & $\mathbf{F}$ \\
\hline & Siphlonuridae & & & A \\
\hline & Tricorythidae & Tricorythodes & minutus & $\mathrm{G}, \mathrm{S}$ \\
\hline & Tricorythidae & Tricorythodes & & $A, F$ \\
\hline \multirow{8}{*}{$\begin{array}{l}\text { Odonata } \\
\text { suborder } \\
\text { Anisoptera } \\
\text { (Dragonflies) }\end{array}$} & & & & \\
\hline & Aeshnidae & Aeshna & & $\mathrm{A}, \mathrm{C}, \mathrm{F}, \mathrm{I}, \mathrm{S}$ \\
\hline & Aeshnidae & Anax & & $\mathrm{H}, \mathrm{P}, \mathrm{S}, 48$ \\
\hline & Aeshnidae & Boyeria & & $\mathrm{L}, \mathrm{S}$ \\
\hline & Cordulegastridae & Cordulegaster & & $\mathrm{F}, \mathrm{S}$ \\
\hline & Corduliidae & Belonia? & & A,C,P \\
\hline & Gomphidae & & & $\mathrm{L}, \mathrm{P}$ \\
\hline & Libellulidae & Leuchorrhina & & I \\
\hline
\end{tabular}




\begin{tabular}{|c|c|c|c|c|}
\hline ORDER & FAMILY & GENUS & SPECIES & $\underset{* \star}{\text { LOCATION }}$ \\
\hline & Libellulidae & Libellula & & PS \\
\hline & Libellulidae & Pantala & & $\mathrm{A}, \mathrm{C}$ \\
\hline & Libellulidae & Platyhemis? & & $\mathrm{P}$ \\
\hline & Libellulidae & Sympetrum? & & PS \\
\hline & Libellulidae & & & $\mathrm{A}, \mathrm{F}, \mathrm{PS}$ \\
\hline \multirow{9}{*}{$\begin{array}{l}\text { suborder } \\
\text { Zygoptera } \\
\text { (Damselflies) }\end{array}$} & Agriidae & Argion & & A \\
\hline & Agriidae & Hetaerina & & A,PS \\
\hline & Coenagrionidae & Argia & & A,C,F,P,S,PS \\
\hline & Coenagrionidae & Enallagma & & $\mathrm{I}, \mathrm{S}$ \\
\hline & Coenagrionidae & Hyponeura & & $F$ \\
\hline & Coenagrionidae & Ishmura & perparua & $\mathrm{F}$ \\
\hline & Coenagrionidae & Ishnura & & $\mathrm{H}, \mathrm{S}$ \\
\hline & Coenagrionidae & Zoniagrion & & $S$ \\
\hline & Lestidae & Archilestes & & PS,S \\
\hline \multirow{14}{*}{$\begin{array}{l}\text { Hemiptera } \\
\text { (True bugs) }\end{array}$} & Corixidae & Corisella & & $\mathrm{F}$ \\
\hline & Corixidae & Sigara & & $\mathrm{F}$ \\
\hline & Corixidae & Trichocorixa & & $\mathrm{A}, \mathrm{P}, \mathrm{S}$ \\
\hline & Gerridae & Gerris & marginatus & $\mathrm{F}$ \\
\hline & Gerridae & Gerris & notabilis & F \\
\hline & Gerridae & Gerris & & $\begin{array}{l}\text { A,D,F,G,H,I, } \\
\text { L,S,PS }\end{array}$ \\
\hline & Gerridae & Metrobates & & PS \\
\hline & Gerridae & Trepobates & & $\mathrm{H}, \mathrm{S}$ \\
\hline & Naucoridae & Ambrysus & mormon & $A, C, P S$ \\
\hline & Notonectidae & Notonecta & undulata & $\mathrm{F}$ \\
\hline & Notonectidae & Notonecta & & $\mathrm{C}, \mathrm{S}$ \\
\hline & Veliidae & Microvelia & & $\mathrm{F}, \mathrm{G}, \mathrm{L}$ \\
\hline & Veliidae & Rhagovelia & & $\mathrm{S}$ \\
\hline & Veliidae & & & A,PS \\
\hline \multirow{7}{*}{$\begin{array}{l}\text { Trichoptera } \\
\text { (Caddisflies) }\end{array}$} & Brachycentridae & Amiocentrus & & $\mathrm{F}$ \\
\hline & Brachycentridae & Brachycentrus & americanus & $\mathrm{F}$ \\
\hline & Brachycentridae & Brachycentrus & & $\mathrm{F}$ \\
\hline & Brachycentridae & Micrasema & & $\mathrm{F}, \mathrm{G}, \mathrm{L}$ \\
\hline & $\begin{array}{l}\text { Brachycentridae } \\
\text { pupae }\end{array}$ & Micrasema & & G \\
\hline & Calamoceratidae & Phylloicus & & $\mathbf{F}$ \\
\hline & Glossomatidae & Agapetus & & G \\
\hline
\end{tabular}




\begin{tabular}{|c|c|c|c|c|}
\hline ORDER & FAMLY & GENUS & SPECIES & $\underset{\star \star \star}{\text { LOCATION }}$ \\
\hline & Glossosomatidae & Anagapetus & & G \\
\hline & Glosssosomatidae & Glossosoma & & $\overline{F, G, L}$ \\
\hline & Helicosychidae & Helicopsyche & borealis & G,L,PS \\
\hline & Helicopsychidae & Helicopsyche & & F \\
\hline & Hydropsychidae & Arctopsyche & grandis & $\mathrm{A}, \mathrm{F}, \mathrm{G}, \mathrm{L}, \mathrm{S}, \mathrm{PS}$ \\
\hline & Hydropsychidae & Cheumatopsyche & & G,PS \\
\hline & Hydropsychidae & Hydropsyche & occentalis & PS \\
\hline & Hydropsychidae & Hydropsyche & oslari & $\mathrm{A}, \mathrm{F}$ \\
\hline & Hydropsychidae & Hydropsyche & & $\mathrm{F}, \mathrm{G}, \mathrm{L}, \mathrm{S}$ \\
\hline & Hydrospsychidae & Hydropsyche & & F,G,PS,S,SG \\
\hline & Hydroptilidae & Alisotrichia & & PS \\
\hline & Hydroptilidae & Hydroptila & & A,P,PS,S \\
\hline & Hydroptilidae & Leucotrichia & & PS \\
\hline & Hydroptilidae & Ochrotrichia & & $\overline{\mathrm{F}, \mathrm{G}, \mathrm{L}}$ \\
\hline & Hydroptilidae & Stactobiella & & A,PS \\
\hline & Lepidostomatidae & Lepidostoma & & $\mathrm{F}, \mathrm{G}, \mathrm{L}, \mathrm{S}, \mathrm{SG}$ \\
\hline & Lepidostomatidae & & & $\mathrm{G}$ \\
\hline & Leptoceridae & Oecetis? & & $\mathrm{G}, \mathrm{L}, \mathrm{P}, \mathrm{S}$ \\
\hline & Limnephilidae & Dicosmoecus & & $\mathrm{F}$ \\
\hline & Limnephilidae & Hesperophylax & & G,L,P,S,SG \\
\hline & $\begin{array}{l}\text { Limnephilidae } \\
\text { pupae }\end{array}$ & Hesperophylax & & $\mathrm{G}$ \\
\hline & Limnephilidae & Limnephilus & & $\mathrm{F}, \mathrm{G}, \mathrm{L}, \mathrm{PW}, \mathrm{S}$ \\
\hline & Limnephilidae & Oligophlebodes & & F,G,L,P,S \\
\hline & $\begin{array}{l}\text { Limnephilidae } \\
\text { pupae }\end{array}$ & Oligophlebodes & & $\mathrm{G}$ \\
\hline & Limnephilidae & Psychoronia & & $\mathrm{F}, \mathrm{G}$ \\
\hline & Limnephilidae & & & G,L,PW \\
\hline & Odontoceridae & Namamyia & & G \\
\hline & Philopotamidae & Chimarra & & A,PS \\
\hline & Philopotamidae & Dolophilodes & aequalis & $\mathbf{F}$ \\
\hline & Philopotamidae & Dolophilodes & sortosa & $\mathrm{F}, \mathrm{G}$ \\
\hline & Philopotamidae & Dolophilodes & & G,L \\
\hline & Philopotamidae & Wormaldia & & F,PS \\
\hline & Polycentropidae & Polycentropus & & $\mathbf{F}$ \\
\hline & Rhyacophilidae & Rhyacophila & acropedes & $\mathrm{F}, \mathrm{G}$ \\
\hline & Rhyacophilidae & Rhyacophila & $\begin{array}{l}\text { brunnea } \\
\text { complex }\end{array}$ & F,G,L \\
\hline & $\begin{array}{l}\text { Rhyacophilidae } \\
\text { pupae }\end{array}$ & Rhyacophila & $\begin{array}{l}\text { brunnea } \\
\text { complex }\end{array}$ & G,L \\
\hline & Rhyacophilidae & Rhyacophila & hyalinata & $\mathrm{F}, \mathrm{G}$ \\
\hline
\end{tabular}




\begin{tabular}{|c|c|c|c|c|}
\hline ORDER & FAMULY & GENUS & SPECIES & $\underset{\star \star \star}{\text { LOCATION }}$ \\
\hline & Rhyacophilidae & Rhyacophila & valuma & $\mathrm{F}, \mathrm{G}$ \\
\hline & Rhyacophilidae & Rhyacophila & & $\bar{F}$ \\
\hline & Rhyacophilidae & Rhyacophila & Type A & A \\
\hline $\begin{array}{l}\text { Megaloptera } \\
\text { (Nerve-wings) }\end{array}$ & Corydalidae & Neohermes? & & G,L \\
\hline \multirow{5}{*}{$\begin{array}{l}\text { Lepidoptera } \\
\text { (Butterflies } \\
\text { and moths) } \\
\end{array}$} & Noctuidae & & & G,L,PS \\
\hline & Pyralidae & & & $\mathrm{G}, \mathrm{S}$ \\
\hline & Pyralidae & Paraponyx & & PS \\
\hline & Pyralidae & Parargyractis & kearfottalis & F,PS \\
\hline & Pyralidae & Petrophyla & & PS \\
\hline \multirow{22}{*}{$\begin{array}{l}\text { Coleoptera } \\
\text { (Beetles) }\end{array}$} & Amphizoidae & Amphizoa & & $\mathrm{G}$ \\
\hline & Curculionidae & Phytonomus & & G,L,S \\
\hline & Curculionidae & & & $\mathrm{D}, \mathrm{F}$ \\
\hline & $\begin{array}{l}\text { Curculionidae } \\
\text { adult }\end{array}$ & & & $\mathrm{G}$ \\
\hline & Dryopidae & Helichus & suturalis* & $\mathbf{F}$ \\
\hline & Dryopidae & Helichus & striatus ${ }^{*}$ & $\mathrm{~F}$ \\
\hline & $\begin{array}{l}\text { Dryopidae } \\
\text { (adults) }\end{array}$ & Helichus & & $\mathrm{F}, \mathrm{G}, \mathrm{L}, \mathrm{P}, \mathrm{PS}, \mathrm{S}$ \\
\hline & $\begin{array}{l}\text { Dryopidae } \\
\text { (adults) }\end{array}$ & & & $S$ \\
\hline & Dytiscidae & Agabus & cordatus* & $\mathrm{F}$ \\
\hline & Dytiscidae & Agabus & tristus* & F \\
\hline & Dytiscidae & Agabus & & $\mathrm{A}, \mathrm{C}, \mathrm{D}, \mathrm{L}, \mathrm{P}, \mathrm{S}$ \\
\hline & Dytiscidae & Deronectes & striatellus* & $F$ \\
\hline & Dytiscidae & Deronectes* & & $\mathrm{L}$ \\
\hline & Dytiscidae & Dytiscus ${ }^{*}$ & & $\mathrm{~F}$ \\
\hline & Dytiscidae & Hydroporus & vilis* & $\mathrm{F}$ \\
\hline & Dytiscidae & Hydroporus & & S \\
\hline & Dytiscidae & Hygrotus & & $\mathrm{S}$ \\
\hline & Dytiscidae & & & $\mathrm{L}, \mathrm{S}$ \\
\hline & $\begin{array}{l}\text { Dytiscidae } \\
\text { (adults) }\end{array}$ & & & G,L,PS,S \\
\hline & $\begin{array}{l}\text { Dytiscidae } \\
\text { (adults) }\end{array}$ & & Type A & $\mathrm{M}, \mathrm{S}$ \\
\hline & \begin{tabular}{|l} 
Dytiscidae \\
(adults)
\end{tabular} & & Type B & $\mathbf{M}, \mathbf{S}$ \\
\hline & $\begin{array}{l}\text { Dytiscidae } \\
\text { (adults) }\end{array}$ & & Type C & S \\
\hline
\end{tabular}




\begin{tabular}{|c|c|c|c|c|}
\hline ORDER & FAMILY & GENUS & SPECIES & $\underset{\star \star}{\text { LOCATION }^{*}}$ \\
\hline & $\begin{array}{l}\text { Dytiscidae } \\
\text { (adults) }\end{array}$ & Hydaticus & & G,L,PS,S \\
\hline & Elmidae & $\begin{array}{l}\text { Cleptelmis } \\
\text { addenda* }\end{array}$ & & $\mathbf{F}$ \\
\hline & Elmidae & Cylloepus & & $\mathbf{F}$ \\
\hline & Elmidae & Dubiraphia* & & G \\
\hline & Elmidae & Heterlimnius & corpulentis & F,G,L,PS,SG \\
\hline & Elmidae (adults) & Heterlimnius & corpulentis & G,L,PS,SG \\
\hline & Elmidae & Microcylloepus ${ }^{*}$ & & PS \\
\hline & Elmidae & Narpus ${ }^{*}$ & concolor & $\mathrm{F}$ \\
\hline & Elmidae & Narpus & & F,G,L \\
\hline & Elmidae (adults) & Narpus & & $\mathrm{G}, \mathrm{L}$ \\
\hline & Elmidae & Optioservus & $\begin{array}{l}\text { castanipennis } \\
*\end{array}$ & $\mathrm{~F}$ \\
\hline & Elmidae & Optioservus & divergens ${ }^{*}$ & $\mathrm{~F}$ \\
\hline & Elmidae & Optioservus* & & $\overline{\mathrm{D}, \mathrm{F}, \mathrm{L}, \mathrm{PS}, \mathrm{S}}$ \\
\hline & Elmidae & Rhizelmis & & $\mathrm{F}$ \\
\hline & Elmidae & Zaitzevia & parvula & $\overline{\mathrm{D}, \mathrm{F}, \mathrm{L}}$ \\
\hline & Elmidae & Zaitzevia & & $\mathrm{G}, \mathrm{L}$ \\
\hline & Elmidae (adults) & Zaitzevia & & $\mathrm{C}, \mathrm{G}, \mathrm{L}, \mathrm{S}$ \\
\hline & Elmidae & & & G,L,S \\
\hline & Elmidae (adults) & & & C,S,PS \\
\hline & Gyrinidae (adults) & Gyrinus & & $\mathrm{A}, \mathrm{F}, \mathrm{S}, \mathrm{PS}$ \\
\hline & Haliplidae & Haliplus & & IC \\
\hline & Haliplidae & Peltodytes & & G \\
\hline & Haliplidae (adults) & & & $\mathbf{s}$ \\
\hline & Helodidae & & & $\mathbf{P}$ \\
\hline & Helodidae & Prionocyphon & & $G$ \\
\hline & Hydrophilidae & Ametor & scabrosus* & $\mathbf{F}$ \\
\hline & Hydrophilidae & Ametor & & $\mathrm{A}, \mathrm{C}, \mathrm{G}, \mathrm{L}, \mathrm{S}$ \\
\hline & $\begin{array}{l}\text { Hydrophilidae } \\
\text { (adults) }\end{array}$ & Ametor & & G \\
\hline & Hydrophilidae & Berosus & styliferous & $\bar{F}$ \\
\hline & Hydrophilidae & Crenitis* & & $\bar{F}$ \\
\hline & Hydrophilidae & Cymbiodyta & dorsalis* & 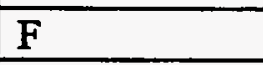 \\
\hline & $\begin{array}{l}\text { Hydrophilidae } \\
\text { (adults) }\end{array}$ & Enochrus? & & $\mathrm{G}$ \\
\hline & $\begin{array}{l}\text { Hydrophilidae } \\
\text { (adults) }\end{array}$ & Helphorus & & $\mathrm{L}$ \\
\hline & $\begin{array}{l}\text { Hydrophilidae } \\
\text { (adults) }\end{array}$ & Hydrobius & & $\mathrm{L}$ \\
\hline
\end{tabular}




\begin{tabular}{|c|c|c|c|c|}
\hline ORDER & FAMILY & GENUS & SPECIES & $\underset{\star \star \star}{\text { LOCATION }}$ \\
\hline & Hydrophilidae & Hydrochus & & $\mathrm{G}$ \\
\hline & $\begin{array}{l}\text { Hydrophilidae } \\
\text { (adults) }\end{array}$ & Hydrochus & & $\bar{G}$ \\
\hline & Hydrophilidae & & & G,L,P \\
\hline & $\begin{array}{l}\text { Hydrophilidae } \\
\text { (adults) }\end{array}$ & & & G \\
\hline & Psephenidae & Psphemus? & & $\mathrm{C}, \mathrm{P}, 48$ \\
\hline & Psephenidae & & & $\mathrm{G}$ \\
\hline \multirow{28}{*}{$\begin{array}{l}\text { Diptera } \\
\text { (Flies) }\end{array}$} & Blephariceridae & & & $\bar{F}$ \\
\hline & $\begin{array}{l}\text { Ceratopogonidae } \\
\text { (Heleidae) }\end{array}$ & Bezzia & & G,L,S \\
\hline & $\begin{array}{l}\text { Ceratopogonidae } \\
\text { (Heleidae) }\end{array}$ & & & F,G,P,S,PS \\
\hline & Chironomidae & Ablabesmyia & & $\bar{F}$ \\
\hline & Chironomidae & Brillia & & $\mathrm{F}, \mathrm{L}, \mathrm{S}$ \\
\hline & Chironomidae & Cardiocladius & & $\mathrm{F}, \mathrm{G}$ \\
\hline & Chironomidae & Crichotopus & & $\mathrm{F}$ \\
\hline & Chironomidae & Chironomus & & $\mathrm{F}$ \\
\hline & Chironomidae & Corynoneura & & PS \\
\hline & Chironomidae & Cricotopus & & A,F,G,PS \\
\hline & Chironomidae & Cryptochironomus & & $\mathrm{F}$ \\
\hline & Chironomidae & Eukiefferiella & & A,F,G,L \\
\hline & Chironomidae & Micropsectra & & $\mathrm{A}, \mathrm{F}$ \\
\hline & Chironomidae & Microtendipes & & $\overline{D, F}$ \\
\hline & Chironomidae & Nanocladius & & $\mathrm{F}$ \\
\hline & Chironomidae & Pagastia & & $\mathrm{L}$ \\
\hline & Chironomidae & Polypedilum & & $\overline{A, F}$ \\
\hline & Chironomidae & Procladius & & $\mathrm{F}$ \\
\hline & Chironomidae & Pseudochironomus & & $\bar{A}$ \\
\hline & Chironomidae & Pseudosmittia & & $\mathrm{G}$ \\
\hline & Chironomidae & Rheotanytarsus & & A,F,PS \\
\hline & Chironomidae & Thienemannimyia & & $\mathrm{A}, \mathrm{S}$ \\
\hline & Chironomidae & Thienimanniella & & $\mathrm{A}$ \\
\hline & Chironomidae & Zavrelia & & $F$ \\
\hline & Chironomidae & Type A & & $\begin{array}{l}\text { C,G,H,L,P, } \\
\text { PS,S,SG, } 128\end{array}$ \\
\hline & Chironomidae & Type B & & G,L,P,S,PS \\
\hline & Chironomidae & Type C & & $\begin{array}{l}G, H, L, P, S, 12 \\
8\end{array}$ \\
\hline & Chironomidae & Type D & & G,L,P,PS,S \\
\hline
\end{tabular}




\begin{tabular}{|c|c|c|c|c|}
\hline ORDER & FAMULY & GENUS & SPECIES & $\underset{\star \star}{\text { LOCATION }}$ \\
\hline & Chironomidae & Type E & & G,L,PS \\
\hline & Chironomidae & Type F & & G,L,S \\
\hline & Chironomidae & Type G & & $\begin{array}{l}\text { A,C,G,H,L,P, } \\
\text { PS,S }\end{array}$ \\
\hline & $\begin{array}{l}\text { Chironomidae } \\
\text { pupae }\end{array}$ & Type G & & $\mathrm{G}$ \\
\hline & Chironomidae & Type H & & $\mathrm{L}, \mathrm{S}$ \\
\hline & Chironomidae & Type I & & SG \\
\hline & $\begin{array}{l}\text { Chironomidae } \\
\text { (pupae) }\end{array}$ & & & $\mathrm{C}, \mathrm{G}, \mathrm{I}, \mathrm{L}, \mathrm{S}$ \\
\hline & $\begin{array}{l}\text { Chironomidae } \\
\text { pupae }\end{array}$ & Type PA & & G,L \\
\hline & $\begin{array}{l}\text { Chironomidae } \\
\text { (pupae) }\end{array}$ & Type PB & & $\mathbf{S}$ \\
\hline & $\begin{array}{l}\text { Chironomidae } \\
\text { (pupae) }\end{array}$ & Type PC & & $\bar{S}$ \\
\hline & Culicidae & Aedes & & $\mathbf{F}$ \\
\hline & Culicidae & Chaoborus & & $\mathrm{I}, 48$ \\
\hline & Culicidae & Culex & & $\mathrm{F}, \mathrm{H}, 128$ \\
\hline & Culicidae & Culiseta & & $\begin{array}{l}\mathrm{D}, \mathrm{H}, \mathrm{M}, 48,12 \\
8\end{array}$ \\
\hline & Culicidae (pupae) & & & H,M,G,L,128 \\
\hline & Culicidae & & & $\mathrm{S}$ \\
\hline & Dixidae & Dixa & californica & $\mathrm{F}$ \\
\hline & Dixidae & Dixa & & F,G,L,PS \\
\hline & Dixidae & Dixa & Type A & G,L,P,PS \\
\hline & Empididae & Chelifera & & $\mathrm{F}, \mathrm{G}, \mathrm{L}$ \\
\hline & Empididae & Oreogeton & & $\mathrm{C}, \mathrm{F}, \mathrm{G}, \mathrm{L}, \mathrm{P}, \mathrm{S}$ \\
\hline & Empididae & & & $\mathrm{H}$ \\
\hline & $\begin{array}{l}\text { Empididae } \\
\text { (pupae) }\end{array}$ & Hemerodromia & & $\mathrm{G}, \mathrm{S}$ \\
\hline & Ephydridae & Brachydeutera & & $\mathbf{S}$ \\
\hline & $\begin{array}{l}\text { Ephydridae } \\
\text { (pupae) }\end{array}$ & & & $S$ \\
\hline & Muscidae & Limnophora & aequifrons & $\mathrm{F}$ \\
\hline & Muscidae & Limnophora & & $\mathrm{A}, \mathrm{D}, \mathrm{L}, \mathrm{S}, \mathrm{SG}$ \\
\hline & Psychodidae & Maruina & & G,L,S \\
\hline & Psychodidae & Pericoma & & $\mathrm{F}, \mathrm{G}, \mathrm{L}$ \\
\hline & $\begin{array}{l}\text { Psychodidae } \\
\text { (pupae) }\end{array}$ & & & $S$ \\
\hline & Ptychopteridae & Bittacomorpha & & $\mathrm{A}, \mathrm{G}, \mathrm{L}, \mathrm{S}$ \\
\hline
\end{tabular}




\begin{tabular}{|c|c|c|c|c|}
\hline ORDER & FAMILY & GENUS & SPECIES & $\underset{\star \star \star}{\text { LOCATION }}$ \\
\hline & Ptychopteridae & Ptychoptera & & $\mathrm{G}$ \\
\hline & Ptychopteridae & & & $\mathrm{F}$ \\
\hline & Simuliidae & Prosimilium & & $\mathrm{A}, \mathrm{F}, \mathrm{G}, \mathrm{L}, \mathrm{S}$ \\
\hline & Simuliidae & Simulium & & $\mathrm{F}, \mathrm{L}$ \\
\hline & Simuliidae & & & D,F,G,L,S,SG \\
\hline & $\begin{array}{l}\text { Simuliidae } \\
\text { (pupae) }\end{array}$ & & & G,L,S \\
\hline & Simuliidae pupae & Type PA & & G \\
\hline & Stratiomyidae & Eulalia & & $\mathrm{F}$ \\
\hline & Stratiomyidae & Odontomyia & & G,PS,S \\
\hline & Stratiomyidae & & & $A, F, G$ \\
\hline & Syrphidae & Tubifera & bastardii & $\mathrm{F}$ \\
\hline & Tabanidae & Chrysops & & $\mathrm{H}, \mathrm{M}$ \\
\hline & Tabanidae & Tabanus & & $128, \mathrm{PW}, \mathrm{S}$ \\
\hline & Tabanidae & & & $\overline{F, G, L, S}$ \\
\hline & Tanyderidae & Protanyderus & & $F$ \\
\hline & Tipulidae & Antocha & monticola & $F, G$ \\
\hline & Tipulidae & Antocha & & $\mathrm{G}, \mathrm{L}$ \\
\hline & Tipulidae & Dicranota & & $\begin{array}{l}\text { F,G,L,PS,S, } \\
\text { SG }\end{array}$ \\
\hline & Tipulidae & Hexatoma & & $\mathrm{F}$ \\
\hline & Tipulidae & Holorusia & grandis & $\mathrm{F}$ \\
\hline & Tipulidae & Limonia & & F \\
\hline & Tipulidae & Pedicia & & $\mathrm{F}$ \\
\hline & Tipulidae & Tipula & & $\mathrm{D}, \mathrm{F}, \mathrm{G}, \mathrm{L}, \mathrm{PS}, \mathrm{S}$ \\
\hline & Tipulidae & Tipula & Type B & $\mathrm{G}, \mathrm{L}, \mathrm{S}$ \\
\hline
\end{tabular}


Non-Insects:

\begin{tabular}{|c|c|c|c|}
\hline $\begin{array}{l}\text { PHYLUM or } \\
\text { SUBPHYLUM }\end{array}$ & CLASS, ETC & COMMON NAME & $\underset{\star \star \star}{\text { LOCATION }}$ \\
\hline \multirow[t]{5}{*}{$\begin{array}{c}\text { Annelida } \\
\text { (Segmented worms) } \\
\end{array}$} & Naididae & Coil worms & $\overline{F, G, L, S}$ \\
\hline & $\begin{array}{l}\text { Oligochaeta, Lumbriculidae } \\
\text { Eiseniella tetraedra }\end{array}$ & Aquatic earthworms & $\mathbf{F}$ \\
\hline & Oligochaeta, Lumbriculidae & Aquatic earthworms & $\begin{array}{l}\text { A,F,G,L,PS, } \\
\text { S,SG }\end{array}$ \\
\hline & $\begin{array}{l}\text { Oligochaeta B, } \\
\text { Lumbriculidae }\end{array}$ & Aquatic earthworms & $\mathrm{G}$ \\
\hline & Hirudinea & Leeches & $\mathrm{A}, \mathrm{F}$ \\
\hline $\begin{array}{l}\text { Arthropoda, Arachnoidea } \\
\text { (Spiders, ticks, and mites) }\end{array}$ & family Hydracarina & Water mites & C,F,G,L,PS,S \\
\hline \multirow[t]{2}{*}{$\begin{array}{c}\text { Aschelminthes } \\
\text { (Round worms and } \\
\text { hairworms) }\end{array}$} & Nematomorpha & Horsehair worm & $\mathrm{C}, \mathrm{F}, \mathrm{G}, \mathrm{L}, \mathrm{P}, \mathrm{S}$ \\
\hline & $\begin{array}{l}\text { Nematomorpha, } \\
\text { Gordioidea, Gordiidae, } \\
\text { Gordius }\end{array}$ & Horsehair worm & $\mathrm{F}, \mathrm{G}$ \\
\hline \multirow[t]{6}{*}{ Crustacea (Crustaceans) } & Amphipoda, Hyatella azteca & Scuds & A,C,PS \\
\hline & Cladocera & Water fleas & 0 \\
\hline & Copepoda & Copepods & $\mathbf{S}$ \\
\hline & Ostracoda, Candoniidae & Seed shrimp & $\mathrm{S}$ \\
\hline & Ostracoda, Cyprididae & Seed shrimp & $\mathrm{C}, \mathrm{S}, \mathrm{SG}$ \\
\hline & Amphipoda, Palaemonidae & Scuds & $\mathrm{A}, \mathrm{C}$ \\
\hline \multirow[t]{9}{*}{ Mollusca (Mollusks) } & Planorbidae, Gyralus parvus & Snails & G,IC,S \\
\hline & Lymnaeidae, Lymnaea & Snails & A,G,L,P,S \\
\hline & Physidae, Physella & Snails & $\mathrm{A}$ \\
\hline & Physidae, Physa & Snails & $\mathrm{F}, \mathrm{S}$ \\
\hline & Gastropoda & Snails & SG \\
\hline & Gastropoda Type A & Snails & G,L \\
\hline & $\begin{array}{l}\text { Sphaeriidae, Pisidium } \\
\text { casertanum }\end{array}$ & Clams & $\mathrm{F}, \mathrm{G}, \mathrm{L}$ \\
\hline & $\begin{array}{l}\text { Pelecypoda, Pisidium } \\
\text { compressa }\end{array}$ & Clams & $\mathbf{H}$ \\
\hline & Sphaeriidae & Clams & $\mathrm{F}$ \\
\hline $\begin{array}{c}\text { Nematoda } \\
\text { (Round worms) }\end{array}$ & & Free-living & $\mathrm{F}, \mathrm{G}, \mathrm{S}$ \\
\hline $\begin{array}{l}\text { Platyhelminthes } \\
\text { (Flatworms) }\end{array}$ & Turbellaria & Planaria & $\begin{array}{l}\text { A,C,F,G,PS, } \\
\text { S,SG }\end{array}$ \\
\hline
\end{tabular}


**Locations:

$$
\begin{aligned}
& \text { A }=\text { Ancho Canyon } \\
& \text { C }=\text { Chaquehui Canyon } \\
& D=\text { DP Canyon } \\
& F=\text { Rio Frijoles and Frijoles Canyon } \\
& \text { G }=\text { Guaje Canyon } \\
& H=\text { High Explosives wastewater stream } \\
& I=\text { Ice House pond, off West Jemez Road } \\
& \text { L }=\text { Los Alamos Canyon } \\
& O=\text { Otowi firestation pond } \\
& M=\text { Mortandad } \\
& \text { PW = Pajarito Wetlands } \\
& \text { PS = Pajarito Springs } \\
& \text { S }=\text { Sandia Canyon }
\end{aligned}
$$




\section{APPENDIX C}

Tolerance Quotients of Aquatic Insects Collected in Sandia Canyon, November 1993 through October 1994

\begin{tabular}{|c|c|c|c|}
\hline Order & Family & Genus (species) & $\begin{array}{c}\text { Tolerance } \\
\text { quotient }\end{array}$ \\
\hline \multirow[t]{3}{*}{ Ephemeroptera } & Baetidae & Baetis & 72 \\
\hline & Baetidae & $\overline{\text { Callibaetis }}$ & 72 \\
\hline & Tricorythidae & Tricorythodes) & 108 \\
\hline \multirow[t]{9}{*}{ Odonata } & Aeshnidae & Aeshna & 72 \\
\hline & Aeshnidae & Anax & 72 \\
\hline & Aeshnidae & & 72 \\
\hline & Coenagrionidae & Argia & 108 \\
\hline & Coenagrionidae & Enallagma & 72 \\
\hline & Coenagrionidae & Ischnura & 72 \\
\hline & Coenagrionidae & & 108 \\
\hline & Cordulegastridae & Cordulegaster & 72 \\
\hline & Lestidae & Archilestes & 108 \\
\hline \multirow[t]{5}{*}{ Hemiptera } & Corixidae & & 108 \\
\hline & Gerridae & Gerris & 72 \\
\hline & Gerridae & Trepobates & 72 \\
\hline & Notonectidae & Notonecta & 108 \\
\hline & Veliidae & Rhagovelia & 72 \\
\hline \multirow[t]{3}{*}{ Trichoptera } & Hydropsychidae & Hydropsyche & 108 \\
\hline & Hydroptilidae & Hydroptila & 108 \\
\hline & Limnephilidae & Hesperophylax & 108 \\
\hline \multirow[t]{4}{*}{ Coleoptera } & Dytiscidae & Hydroporus & 72 \\
\hline & Dytiscidae & Hygrotus & 72 \\
\hline & Dytiscidae & & 72 \\
\hline & Hydrophilidae & Ametor & 72 \\
\hline \multirow[t]{13}{*}{ Diptera } & Ceratopogonidae & & 108 \\
\hline & Chironomidae & & 108 \\
\hline & Culicidae & & 108 \\
\hline & Empididae & Hemerodromia & 108 \\
\hline & Empididae & & 108 \\
\hline & Ephydridae & & 108 \\
\hline & Muscidae & Limnophora & 108 \\
\hline & Psychodidae & Maruina & 36 \\
\hline & Simulidae & & 108 \\
\hline & Tabanidae & Tabanus & 108 \\
\hline & Tabanidae & & 108 \\
\hline & Tipulidae & Dicranota & 24 \\
\hline & Tipulidae & Tipula & 36 \\
\hline
\end{tabular}


Tolerance Quotients of Aquatic Non-Insects Collected in Sandia Canyon (November 1993 - October 1994)

\begin{tabular}{|l|l|l|l|c|}
\hline \multicolumn{1}{|c|}{ Phylum } & \multicolumn{1}{|c|}{ Class } & \multicolumn{1}{|c|}{$\begin{array}{c}\text { Order or } \\
\text { Sub-Class }\end{array}$} & \multicolumn{1}{|c|}{ Family } & $\begin{array}{c}\text { Tolerance } \\
\text { Quotient }\end{array}$ \\
\hline Annelida & Oligochaeta & & Lumbriculidae & 108 \\
\hline Arthropoda & Crustacea & Copepoda & & 108 \\
\hline & Crustacea & Ostracoda & Candoniidae & 108 \\
\hline & Crustacea & Ostracoda & Cyprididae & 108 \\
\hline Mollusca & Gastropoda & Basommatophora & $\begin{array}{l}\text { Lymnaeidae, } \\
\text { Lymnaea }\end{array}$ & 108 \\
\hline & Gastropoda & Basommatophora & $\begin{array}{l}\text { Physidae, } \\
\text { Physa }\end{array}$ & 108 \\
\hline Platyhelminthes & Turbellaria & & & 108 \\
\hline
\end{tabular}




\section{APPENDIX D}

Mode of Existence of Aquatic Insects Collected Sandia Canyon, November 1993 through October 1994

(adapted from An Introduction to the Aquatic Insects, Merritt and Cummins, 1984)

\begin{tabular}{|c|c|c|c|}
\hline Order & Family & Genus & $\begin{array}{l}\text { Mode of } \\
\text { Existence }\end{array}$ \\
\hline \multirow[t]{3}{*}{$\begin{array}{l}\text { Ephemeroptera } \\
\text { (mayflies) }\end{array}$} & Baetidae & Baetis & $\mathrm{sw}, \mathrm{cb}, \mathrm{cg}$ \\
\hline & Baetidae & Callibaetis & $\mathrm{sw}, \mathrm{cb}$ \\
\hline & Tricorythidae & Tricorythodes & $\mathrm{sp}, \mathrm{cg}$ \\
\hline \multirow{9}{*}{$\begin{array}{l}\text { Odonata (dragonflies } \\
\text { and damselflies) }\end{array}$} & Aeshnidae & Aeshna & $\mathrm{cb}$ \\
\hline & Aeshnidae & Anax & $\mathrm{cb}$ \\
\hline & Aeshnidae & Boyeria & cb-sp \\
\hline & Coenagriidae & Argia & $\mathrm{cg}, \mathrm{cb}-\mathrm{sp}$ \\
\hline & Coenagrionidae & Enallagma & $\mathrm{cb}$ \\
\hline & Coenagrionidae & Ishmura & cb \\
\hline & Coenagrionidae & Zonagrion & $\mathrm{cb}$ \\
\hline & Cordulegastridae & Cordulegaster & $\mathrm{bu}$ \\
\hline & Lestidae & Archilestes & cb \\
\hline \multirow[t]{5}{*}{ Hemiptera (true bugs) } & Corixidae & & sw \\
\hline & Gerridae adult & Gerris & sk \\
\hline & Gerridae & Trepobates & sk \\
\hline & Notonectidae & Notonecta & $\mathrm{sw}, \mathrm{cb}$ \\
\hline & Veliidae & Rhagovelia & sk \\
\hline \multirow[t]{4}{*}{$\begin{array}{l}\text { Trichoptera } \\
\text { (caddisflies) } \\
\end{array}$} & Hydropsychidae & Hydropsyche & $\mathrm{cg}$ \\
\hline & Hydroptilidae & Hydroptila & $\mathrm{cg}$ \\
\hline & Lepidostomatidae & Lepidostoma & cb-sp-cg \\
\hline & Limnephilidae & Hesperophylax & $\mathrm{sp}$ \\
\hline \multirow[t]{10}{*}{ Coleoptera (beetles) } & Dryopidae & Helichus adult & $\mathrm{cg}, \mathrm{cb}$ \\
\hline & Dytiscidae & Hydaticus & $c b, d v, s w$ \\
\hline & Dytiscidae & Hydroporus & $\mathrm{cb}, \mathrm{sw}$ \\
\hline & Dytiscidae & Hygrotus & $\mathrm{cb}, \mathrm{sw}$ \\
\hline & Dytiscidae & & $\mathrm{cb}, \mathrm{sw}$ \\
\hline & Dytiscidae adult & & $\mathrm{cb}, \mathrm{sw}$ \\
\hline & Dytiscidae adult & A & $\mathrm{cb}, \mathrm{sw}$ \\
\hline & Dytiscidae adult & B & $\mathrm{cb}, \mathrm{sw}$ \\
\hline & Dytiscidae adult & $\mathrm{C}$ & $\mathrm{cb}, \mathrm{sw}$ \\
\hline & Hydrophilidae & Ametor & $\mathrm{cg}$ \\
\hline
\end{tabular}




\begin{tabular}{|l|l|l|l|}
\hline Order & Family & Genus & $\begin{array}{l}\text { Mode of } \\
\text { Existence }\end{array}$ \\
\hline Diptera (flies) & Ceratopogonidae & Bezzia & bu \\
\hline & Chironomidae & A & \\
\hline & Chironomidae & B & \\
\hline & Chironomidae & C & \\
\hline & Chironomidae & G & \\
\hline & Culicidae & & sw \\
\hline & Empididae & Hemerodromia & bu,sp \\
\hline & Ephydridae & Brachydeutera & bu,sp \\
\hline & Muscidae & Limnophora & bu \\
\hline & Psychodidae & Maruina & bu \\
\hline & Simulidae & & $\mathrm{cg}$ \\
\hline & Tabanidae & Tabanus & bu,sp \\
\hline & Tabanidae & & bu,sp \\
\hline & Tipulidae & TipulaB & bu \\
\hline & Tipulidae & Tipula & bu \\
\hline & & &
\end{tabular}

Abbreviations used in table:

$$
\begin{aligned}
& \mathrm{bu}=\text { burrower } \\
& \mathrm{cb}=\text { climber } \\
& \mathrm{cg}=\text { clinger } \\
& \mathrm{dv}=\text { diver } \\
& \mathrm{sk}=\text { skater } \\
& \mathrm{sp}=\text { sprawler } \\
& \mathrm{sw}=\text { swimmer }
\end{aligned}
$$




\section{APPENDIX E}

\section{Functional Feeding Groups of Aquatic Insects Collected Sandia Canyon}

November 1993 through October 1994

(adapted from An Introduction to the Aquatic Insects, Merritt and Cummins, 1984)

\begin{tabular}{|c|c|c|c|}
\hline Order & Family & Genus & $\begin{array}{l}\text { Functional } \\
\text { Feeding Group }\end{array}$ \\
\hline \multirow{3}{*}{$\begin{array}{l}\text { Ephemeroptera } \\
\text { (mayflies) }\end{array}$} & Baetidae & Baetis & $\mathrm{cg}, \mathrm{sc}$ \\
\hline & Baetidae & Callibaetis & $\mathrm{cg}$ \\
\hline & Tricorythidae & Tricorythodes & $\mathrm{cg}$ \\
\hline \multirow{10}{*}{$\begin{array}{l}\text { Odonata (dragonflies } \\
\text { and damselflies) }\end{array}$} & Aeshnidae & Anax & $\mathrm{pr}$ \\
\hline & Aeshinidae & Boyeria & $\mathrm{pr}$ \\
\hline & Aeshinidae & & \\
\hline & Coebagruibudae & Argia & $\mathrm{pr}$ \\
\hline & Coenagrionidae & Enhallagma & $\mathrm{pr}$ \\
\hline & Coenagrionidae & Ishnura & $\mathrm{pr}$ \\
\hline & Coenagrionidae & Zonagrion & $\mathrm{pr}$ \\
\hline & Coenagrionidae & & $\mathrm{pr}$ \\
\hline & Cordulegastridae & Cordulegaster & $\mathrm{pr}$ \\
\hline & Lestidae & Archilestes & $\mathrm{pr}$ \\
\hline \multirow[t]{5}{*}{ Hemiptera (true bugs) } & Corixidae & & he,pr,sc \\
\hline & Gerridae & Gerris & pr \\
\hline & Gerridae & Trepobates & $\mathrm{pr}$ \\
\hline & Notonectidae & Notonecta & $\mathrm{pr}$ \\
\hline & Veliidae & Rhagovelia & $\mathrm{pr}$ \\
\hline \multirow[t]{3}{*}{$\begin{array}{l}\text { Trichoptera } \\
\text { (caddisflies) }\end{array}$} & Hydropsychidae & Hydropsyche & cf \\
\hline & Hydroptilidae & Hydroptila & he,sc,cg \\
\hline & Limnephilidae & Hesperophylax & sh \\
\hline \multirow[t]{4}{*}{ Coleoptera (beetles) } & Dytiscidae & Hydaticus & $\mathrm{pr}$ \\
\hline & Dytiscidae & Hydroporus & $\mathrm{pr}$ \\
\hline & Dytiscidae & Hygrotus & $\mathrm{pr}$ \\
\hline & Dytiscidae adult & & $\mathrm{pr}$ \\
\hline \multirow[t]{6}{*}{ Diptera (flies) } & Ceratopogonidae & Bezzia & $\mathrm{pr}$ \\
\hline & Chironomidae & & $\mathrm{cg}$ or $\mathrm{pr}$ \\
\hline & Culicidae & & cg.cf \\
\hline & Empididae & Hemerodromia & $\mathrm{pr}, \mathrm{cg}$ \\
\hline & Ephydridae & Brachydeutera & cg \\
\hline & Muscidae & Limnophora & pr \\
\hline
\end{tabular}




\begin{tabular}{|l|l|l|l|}
\hline Order & Family & Genus & $\begin{array}{l}\text { Functional } \\
\text { Feeding Group }\end{array}$ \\
\hline & Psychodidae & Maruina & sc,cg \\
\hline & Simulidae & & $\mathrm{cf}$ \\
\hline & Tabanidae & Tabanus & $\mathrm{pr}$ \\
\hline & Tabanidae & & $\mathrm{pr}$ \\
\hline & Tipulidae & Dicranota & $\mathrm{pr}$ \\
\hline & Tipulidae & Tipula B & $\mathrm{sh}$ \\
\hline
\end{tabular}

Abbreviations used in table:

$$
\begin{aligned}
& \mathrm{cf}=\text { collector filterers } \\
& \mathrm{cg}=\text { collector gatherers } \\
& \mathrm{he}=\text { herbivores } \\
& \mathrm{pr}=\text { predators } \\
& \mathrm{sc}=\text { scrapers } \\
& \mathrm{sh}=\text { shredders }
\end{aligned}
$$

